\title{
Intensification of Chemical Looping Processes by Catalyst Assistance and Combination
}

\author{
Hilde Poelman (D) and Vladimir V. Galvita *(D) \\ Laboratory for Chemical Technology, Ghent University, Technologiepark 125, B-9052 Ghent, Belgium; \\ hilde.poelman@UGent.be \\ * Correspondence: Vladimir.Galvita@UGent.be; Tel.: +32-4-6810-6004
}

check for updates

Citation: Poelman, H.; Galvita, V.V. Intensification of Chemical Looping Processes by Catalyst Assistance and Combination. Catalysts 2021, 11, 266. https://doi.org/10.3390/catal 11020266

Academic Editors: Juan

J. Bravo-Suarez and Valerie Dupont

Received: 7 January 2021

Accepted: 11 February 2021

Published: 17 February 2021

Publisher's Note: MDPI stays neutral with regard to jurisdictional claims in published maps and institutional affiliations.

Copyright: (C) 2021 by the authors Licensee MDPI, Basel, Switzerland. This article is an open access article distributed under the terms and conditions of the Creative Commons Attribution (CC BY) license (https:// creativecommons.org/licenses/by/ $4.0 /)$.

\begin{abstract}
Chemical looping can be considered a technology platform, which refers to one common basic concept that can be used for various applications. Compared with a traditional catalytic process, the chemical looping concept allows fuels' conversion and products' separation without extra processes. In addition, the chemical looping technology has another major advantage: combinability, which enables the integration of different reactions into one process, leading to intensification. This review collects various important state-of-the-art examples, such as integration of chemical looping and catalytic processes. Hereby, we demonstrate that chemical looping can in principle be implemented for any catalytic reaction or at least assist in existing processes, provided that the targeted functional group is transferrable by means of suitable carriers.
\end{abstract}

Keywords: dry reforming; ammonia synthesis; oxygen storage materials; hydrogen production; oxidative dehydrogenation; energy storage; iron; sorption enhanced; super-dry reforming

\section{Concept of Chemical Looping}

Currently, there is significant effort to resign our dependence on fossil resources and to minimize the emission of carbon dioxide [1,2]. Clearly, this calls for new and improved catalytic processes and for catalytic technologies that focus on prevention rather than on remediation [3]. To be honest, at present, no efficient technologies exist that enable the use of $\mathrm{CO}_{2}$ as starting or raw material [4-6]. Such processes could however serve the dual purpose of producing value-added chemicals using $\mathrm{CO}_{2}$ as a $\mathrm{C}_{1}$ base chemical and reducing $\mathrm{CO}_{2}$ emissions. If this were to be carried out at a large scale, say megatons, it would definitely help with mitigating climate change effects by recycling part of the waste $\mathrm{CO}_{2}$, while creating new opportunities for the chemical industry. What to do? A possible solution can be provided by chemical looping [7-16], a promising technology of low emission, with applications in electricity or heat production, as well as in chemicals and fuels. This novel technology is rapidly evolving towards an established "clean combustion" due to the intrinsic, very efficient $\mathrm{CO}_{2}$ separation. However, the term chemical looping (CL) is not limited to combustion but can be used in a much broader sense to describe a specific type of reaction scheme. In chemical looping, a conventional catalytic reaction is split in sub-reactions, using intermediates that react and are regenerated in a cyclic way. Based on the type of intermediate, chemical looping processes can be classified in three groups:

1. Chemical looping of redox reactions [8,11-15]. Herein, a metal oxide (MO) acts as oxygen storage material (OSM) (M: reduced form), which takes up oxygen from the oxidant (e.g., $\mathrm{H}_{2} \mathrm{O}, \mathrm{O}_{2}$ or $\mathrm{CO}_{2}$ ) and passes it on to the reductant (e.g., $\mathrm{C}, \mathrm{H}_{2}, \mathrm{CH}_{4}$, plastic, etc.) (Figure 1a). By dividing the global reaction in two, the reduced and oxidized products can be separated by running the sub-reactions at two different times or places (temporal or spatial separation). Even solid fuels can be oxidized by appropriate chemical looping materials at a quite reasonable rate. However, the technology of chemical looping is not limited to oxidation only. On the contrary, 
combinations of oxygen carriers with other carrier materials can cover a very diverse field of reactions.

2. Chemical looping separation of carbon dioxide [8,15-22]. Chemical looping $\mathrm{CO}_{2}$ separation applies an (earth) alkali metal oxide (MO) as sorbent, to reversibly retain and set free $\mathrm{CO}_{2}$ (Figure $1 \mathrm{~b}$ ). The process of $\mathrm{CO}_{2}$ storing is called carbonation because it transforms $\mathrm{MO}$ into the corresponding carbonate $\mathrm{MCO}_{3}$. The opposite process takes place upon heating, thereby releasing the $\mathrm{CO}_{2}$ (decarbonation). By alternating $\mathrm{MO}$ carbonation and decarbonation, $\mathrm{CO}_{2}$ can be separated from exhaust gases or other dilute streams. The oxygen storage and $\mathrm{CO}_{2}$ sorbent materials of the processes 1 and 2 can easily be regenerated and hence reused in the next cycle $[8,15,18]$.

3. Transfer of surface reaction intermediates by chemical looping (carbon, $-\mathrm{OH}, \mathrm{S}$, etc.) between distinct reactions $[23,24]$. Materials in these chemical looping processes can carry reaction intermediates, which are different from oxygen or $\mathrm{CO}_{2}$ (Figure 1c). As intermediates form on the surface of the carrier in one step, they are subsequently used in the next. For example, Ni and $\mathrm{Zn}$ materials can be used to carry carbon and sulfur, respectively.

The installation of a chemical looping process either requires fixed-bed reactors (number of reactors $\geq 2$ ) (Figure $1 \mathrm{~d}$ ) or alternatively, two interconnected fluidized-bed reactors (Figure 1e).
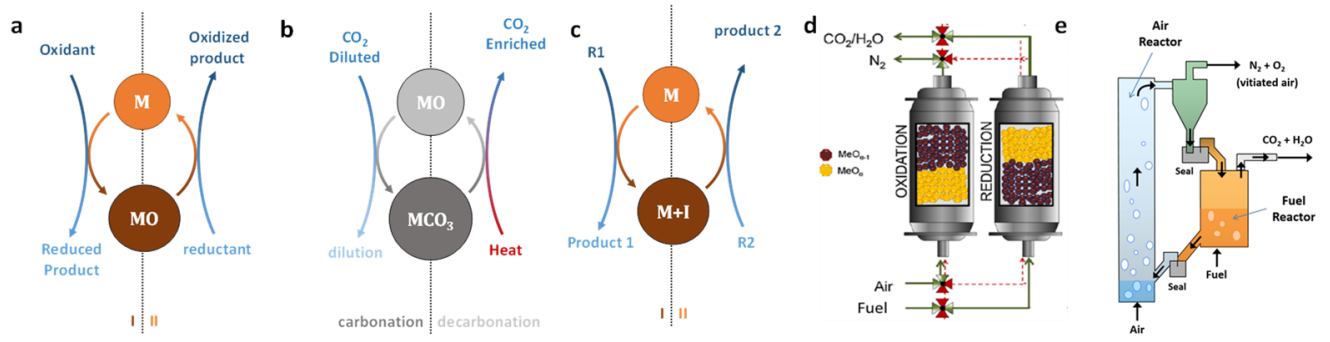

Figure 1. Scheme of some chemical looping processes for: (a) redox reactions and (b) carbon dioxide separation. In $(\mathbf{a}, \mathbf{b})$ reduction and decarbonation can equally be achieved by oxygen and carbon dioxide partial pressure decrease, e.g., through an inert gas feed. (c) Chemical looping transfer, where solid materials pass on surface reaction intermediates (carbon, $-\mathrm{OH}, \mathrm{S}$,) between separate reactions (R1 and R2). Chemical looping using (d) fixed-bed reactors and (e) two interconnected fluidized-bed reactors.

Considering that it can have various applications, starting from one common basic concept, chemical looping can be considered a true technology platform. Compared to a traditional catalytic process, the chemical looping concept allows to: (i) minimize exergy loss $[8,25,26]$, (ii) intensify the targeted process by combining reaction and separation in a single step [27], (iii) apply $\mathrm{H}_{2} \mathrm{O} / \mathrm{CO}_{2}$ as an oxidant (steam/dry reforming), which enables to produce pure $\mathrm{H}_{2}$ and $\mathrm{CO}$ without the need for downstream separation $[8,28,29]$, (iv) feed lower grade or less pure feedstocks, (v) use cheap materials $\left(\mathrm{CaO}, \mathrm{FeO}_{\mathrm{x}}\right)[13,30]$ and (vi) use fuel without the need for upstream desulfurization [23,31]. A quite notable feature is its ability to provide product separation in situ. Since separation is very energy-intensive, the product separation in chemical looping offers valuable prospects of energy savings and emission reductions.

Next to the above intrinsic qualities, chemical looping has another major advantage: combinability, which allows for integration of different reactions into one process, leading to intensification. Several of the above-mentioned processes are then combined into more advanced chemical looping schemes, such as, e.g., in chemical looping methane reforming enhanced by sorption, or in super-dry reforming, or they are coupled with catalytic reactions, such as, e.g., in catalyst-assisted chemical looping. This review collects various important state-of-the-art examples of such integrations of catalytic processes and chemical looping and the role of multifunctional materials therein. 


\section{Catalyst-Assisted Chemical Looping}

The role that hydrogen plays nowadays in the chemical industry, in parallel to its contribution to energy supply, cannot be underestimated. Currently, hydrogen is mainly used for ammonia production (62\%), refining industry (24\%), methanol production ( $8 \%$, metallurgy, in manufacture of high-quality electronic components and in many more applications. There is no doubt that the demand for hydrogen will further rise, both in existing industries and in new technologies like fuel cells [32,33]. A typical process to produce hydrogen comprises methane steam reforming, then water gas shift and a final pressure swing adsorption for purification [34,35]. One or two separate reactors are required for the water gas shift reaction: the high-temperature shift reactor with an iron/chrome catalyst, operating at $350-500{ }^{\circ} \mathrm{C}$. Hereafter, a CO concentration of around 4 $\mathrm{mol} \%$ on dry basis is present in the outlet stream. To reach a lower CO concentration, a second reactor working at lower temperature is needed. Finally, a preferential oxidation reactor (PROX) or pressure swing adsorption reduces the $\mathrm{CO}$ concentration down to the ppm level. The need for such a reactor train means, however, a significant decrease in full process efficiency.

To shorten this conventional production chain, one can consider a chemical looping concept for methane reforming. Such process generates high-purity hydrogen (with carbon oxides at the ppm level) starting from hydrocarbons. Although this is still a two-step process, only a single reactor is required without any post-processing, meaning significant economic profit. Central to this technology are cheap and abundant iron oxide materials, which are to be reduced/re-oxidized periodically, a process in which they transfer oxygen. In the first step, iron oxide gets reduced by methane (or renewable biogas), while the second stage brings the reduced iron back to an oxidized state by feeding steam as an oxidant. Together with the material re-oxidation, hydrogen is being produced.

Obviously, the deeper the oxygen storage material can be reduced, the more hydrogen can be generated upon re-oxidation. In the above process description, reduction of iron oxide, in particular $\mathrm{Fe}_{3} \mathrm{O}_{4}$, by methane is slow, so that it limits the attainable degree of reduction [36]. If biogas, a mixture of carbon dioxide and methane, is used as a source of methane, iron oxide reduction is drastically decreased, because it is opposed by carbon dioxide acting as an oxidant [37,38], see Figure 2. Actually, this effect is induced by both feed and product $\mathrm{CO}_{2}$, counteracting the iron oxide reduction by methane. To circumvent this drawback, the oxygen storage material bed can be foreseen of a Ni-based catalyst in addition to the iron oxide, either in layers or as physical mixture [39]. The Ni-based catalyst will convert the $\mathrm{CH}_{4}$ and $\mathrm{CO}_{2}$ mixture to syngas, i.e., $\mathrm{H}_{2}+\mathrm{CO}$, by dry reforming. The latter gases ensure a deeper reduction of iron oxide than with $\mathrm{CH}_{4}$. The dry reforming of methane is recently gaining interest as it converts two greenhouse gases as a carbon source. Not only does it produce syngas, which compared to methane has a higher reduction potential, but it also consumes $\mathrm{CO}_{2}$ from the feed, allowing for deeper reduction of iron oxide, and as a result, for a larger amount of $\mathrm{H}_{2}$ to be produced in the second re-oxidation step. This is an example of synergy between catalysis over $\mathrm{Ni}$ and chemical looping using $\mathrm{Fe}_{3} \mathrm{O}_{4}$, in a so-called "catalyst-assisted chemical looping process".

Chemical looping allows to easily switch between desired products. If in the reoxidation step steam is replaced by $\mathrm{CO}_{2}$ as an oxidizing agent, the process turns into chemical looping dry reforming (CLDR). Compared to the conventional form of catalytic dry reforming (DR), CLDR solves some challenges and brings advantages:

- First, removal of deposited carbon: this important issue of DR is solved as carbon will react with $\mathrm{CO}_{2}$ in every regeneration step of the looping material.

- Second, the use of $\mathrm{CO}_{2}$ as an oxidant for material regeneration in the re-oxidation allows to convert more $\mathrm{CO}_{2}$ than in the conventional reaction, namely three times more in CLDR than in DR [40]. As such, the target of chemical looping dry reforming is no longer a high syngas yield as for DR, but rather optimal activation and utilization of $\mathrm{CO}_{2}$. A proof of principle for the CLDR process was described by Najera et al. [40]. Based on thermodynamic calculations to select suitable oxygen storage materials, 
they synthesized and characterized carriers with nanostructure that showed high activity and stability, showing the potential of the CLDR concept. In addition, reactor modelling evidenced the practical feasibility of the process [40,41].

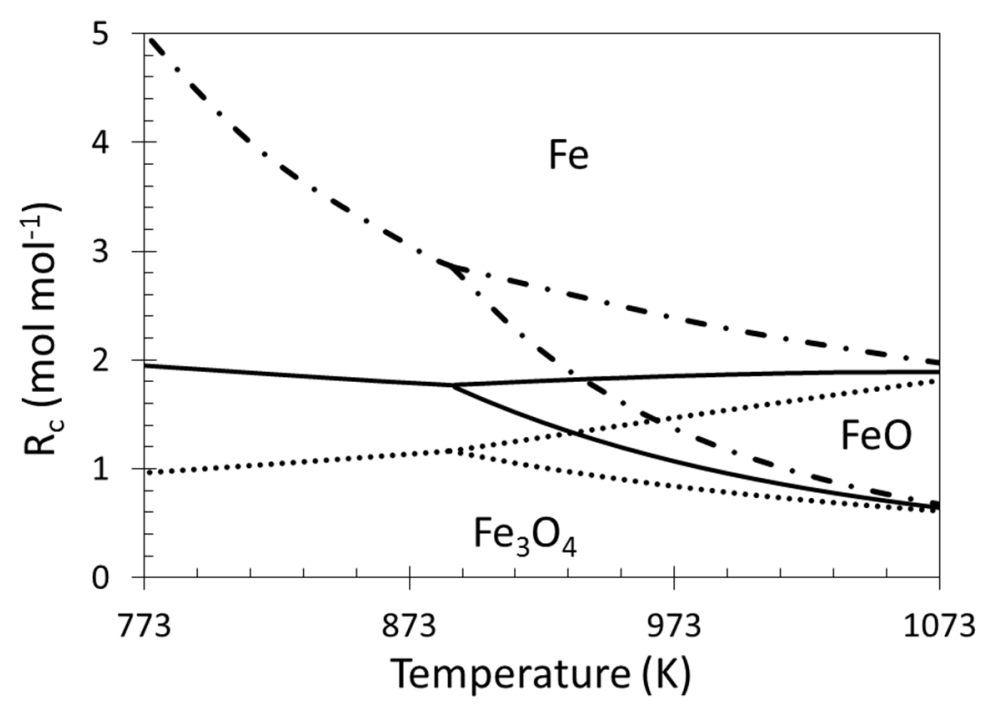

Figure 2. Phase diagram for the equilibrium between iron and its oxides $\left(\mathrm{Fe}_{3} \mathrm{O}_{4}, \mathrm{FeO}\right.$ and $\left.\mathrm{Fe}\right)$ as a function of temperature and feed gas reduction capacity: -. - $\mathrm{H}_{2} / \mathrm{H}_{2} \mathrm{O} ;-\mathrm{H}_{2} / \mathrm{CO} / \mathrm{H}_{2} \mathrm{O} / \mathrm{CO}_{2}(\mathrm{C}$ and $\mathrm{H}_{2}$ equimolar amount, representing a feed of $\left.\mathrm{CH}_{4}+\mathrm{CO}_{2}\right) ; \cdots \cdot \mathrm{CO} / \mathrm{CO}_{2}$ [38].

The entire concept of the CLDR process stands or falls with the selection of a suitable storage material. Herein, cost, stability and above all reactivity are of the essence. Based on thermodynamic data for reduction and re-oxidation, a wide range of metals/metal oxides were considered [40,42]. While some of these, like $\mathrm{Mo}, \mathrm{Cr}, \mathrm{Zn}, \mathrm{Co}, \mathrm{Nb}$ and $\mathrm{Ce}$, give reasonable $\mathrm{CO}_{2}$ conversion capacity, the highest oxygen storage capacity from $\mathrm{CO}_{2}$ is provided by $\mathrm{Fe}$, namely $0.7 \mathrm{~mol} \mathrm{CO} / \mathrm{mol}_{\mathrm{Fe}}$, at temperatures $>600^{\circ} \mathrm{C}$. This makes $\mathrm{CO}_{2}$ conversion to $\mathrm{CO}$ by chemical looping over an Fe-containing material for oxygen storage a most promising technology. Nevertheless, issues still remain with respect to the process economics, in particular, how to keep up the activity during multiple cycles of reduction/oxidation? Several factors play a role in this. For one, the surface area of $\mathrm{FeO}$ influences the reactivity in $\mathrm{CO}_{2}$ splitting, as found by Loutzenhiser et al. [43]. However, high surface area iron oxides are more susceptible for sintering, an irreversible process, so they rapidly loose activity [44]. The iron oxide lost more than $70 \%$ of the initial activity during the first 8 redox cycles. Hence, the viability of the $\mathrm{CO}_{2}$ conversion process by CLDR, compared to other technologies, can only benefit from iron oxide sintering control during redox cycling to maintain its reactivity. The further optimization of the process thus relies on fundamental studies on the impact of structural and compositional design of the metal oxide and/or catalyst components at the nanoparticle level, as well as of the support on the overall performance.

Catalysts based on $\mathrm{Ni}$ are among the most investigated, even given their deactivation by carbon accumulation [45]. They make active and stable catalysts for dry reforming of methane, especially when they are well dispersed. Support materials can help to disperse $\mathrm{Ni}$, and if they have redox properties, like solid solutions or mixed oxides based on ceria, they can also take care of carbon removal. Pure $\mathrm{CeO}_{2}$ for instance promotes $\mathrm{Ni}$ dispersion, while its redox couple $\mathrm{Ce}^{4+} / \mathrm{Ce}^{3+}$ easily gasifies carbon accumulated at the surface by supplying active oxygen. A Ni-CeO $/$ mineral clay catalyst, studied by Daza et al. [46], showed enhanced activity and limited coke formation in methane dry reforming, ascribed to the better dispersion of $\mathrm{Ni}$ and improved $\mathrm{CO}_{2}$ adsorption. Also, Potdar et al. [47] reported about a Ni-Ce catalyst with high surface area showing stable activity and resistance to coke formation in reforming because of high oxygen mobility. In 
a similar redox support approach, Ni has been modified with $\mathrm{Fe}$, which also has high redox capacity, just like the Ce species [45]. In this type of design, the support carries both the catalytic and oxygen storage component, making it a multifunctional material. The different functions work together in both steps of the chemical looping dry reforming process: upon reduction, the mixed feed of $\mathrm{CH}_{4}+\mathrm{CO}_{2}$ is converted over $\mathrm{Ni}$ to syngas, which reduces both $\mathrm{Fe}_{2} \mathrm{O}_{3}$ and $\mathrm{CeO}_{2}$, thereby producing $\mathrm{CO}_{2}$ and $\mathrm{H}_{2} \mathrm{O}$. Ni ensures deeper reduction of the oxide materials. In the re-oxidation stage, the reduced material is regenerated by $\mathrm{CO}_{2}$ to produce $\mathrm{CO}$. The benefit of combining catalyst and oxygen storage functions was obvious as the $\mathrm{CO}$ yield turned out to be 10 -fold of the one for $\mathrm{Fe}_{2} \mathrm{O}_{3}-\mathrm{CeO}_{2}$ without Ni catalyst [48].

Figure 3 shows the multifunctional $5 \% \mathrm{Ni} / \mathrm{Fe}_{2} \mathrm{O}_{3}-\mathrm{CeO}_{2}$ sample in transmission electron microscopy (TEM). The high-resolution image displays crystallites with a size of $\sim 17 \mathrm{~nm}$, all bearing a similar morphology (Figure 3a). Energy-dispersive X-ray spectroscopy (EDX)-STEM (Scanning Transmission Electron Microscopy) mapping provided the elemental distribution in the material, showing that $\mathrm{Ni}$ (red) prefers to be close to or on the $\mathrm{Fe}_{2} \mathrm{O}_{3}$ (blue) particles (Figure 3b).
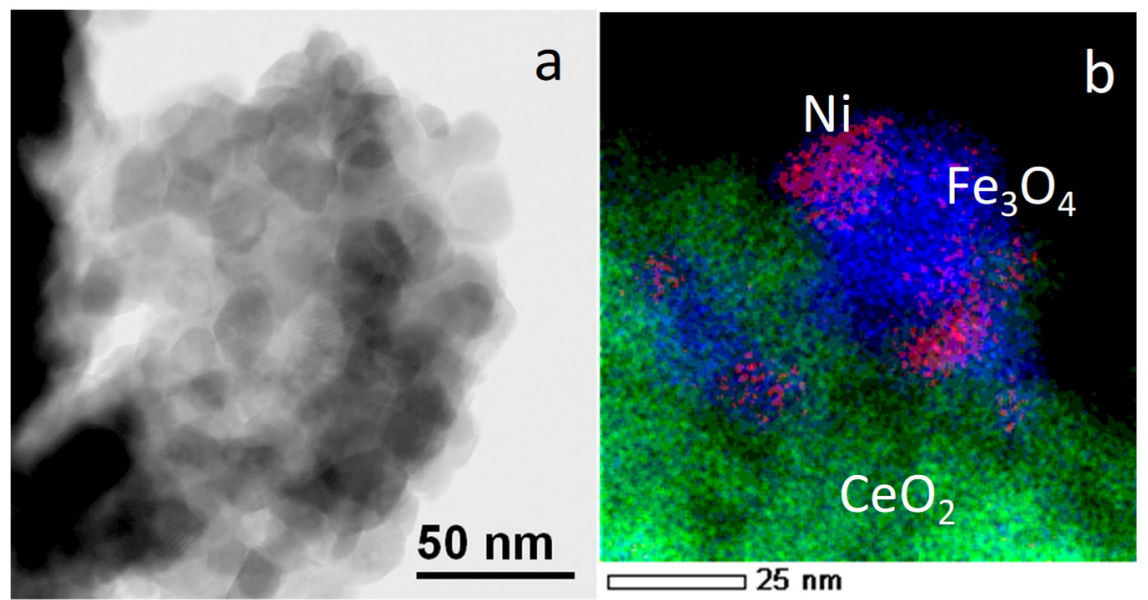

Figure 3. Transmission electron microscopy micrograph of $5 \% \mathrm{Ni} / \mathrm{Fe}_{2} \mathrm{O}_{3}-\mathrm{CeO}_{2}$ (a) and (b) higher magnification to show the energy-dispersive $\mathrm{X}$-ray spectroscopy (EDX) element mappings of Fe (blue), Ce (green) and Ni (red), close to each other [48].

Together with DR, side reactions can occur depending on the operating temperature and partial pressure of the reactants. These comprise $\mathrm{CH}_{4}$ decomposition (Equation (1)) as well as the Boudouard reaction (Equation (2)), where CO transforms into surface carbon and $\mathrm{CO}_{2}$ :

$$
\begin{aligned}
& \mathrm{CH}_{4} \rightarrow \mathrm{C}(\mathrm{s})+2 \mathrm{H}_{2} \\
& 2 \mathrm{CO} \leftrightarrow \mathrm{C}(\mathrm{s})+\mathrm{CO}_{2}
\end{aligned}
$$

Re-oxidizing the reduced $\mathrm{Ni} / \mathrm{Fe}_{2} \mathrm{O}_{3}-\mathrm{CeO}_{2}$ with $\mathrm{CO}_{2}$, while applying in situ X-ray diffraction (XRD), yields interesting details. A set of patterns was recorded during a few oxidation/inert/dry reforming cycles at $873 \mathrm{~K}$ (Figure 4). Reaction temperature was reached with a high heating rate up to $873 \mathrm{~K}$, temperature which was then maintained. Depending on the gas environment present throughout the chemical looping experiment, $\mathrm{He}, \mathrm{CO}_{2}$ or $\mathrm{CO}_{2}+\mathrm{CH}_{4}$, the background intensity of the whole pattern varied because of differences in X-ray scattering. The first reduction treatment under $\mathrm{CH}_{4}+\mathrm{CO}_{2}$ forms $\mathrm{Fe}$ with main diffraction at $45^{\circ}$ and the $\mathrm{Ni}_{3} \mathrm{Fe}$ alloy after $100 \mathrm{~s}$. Upon introduction of $\mathrm{CO}_{2}$ into the reactor after $5 \mathrm{~min}, \mathrm{Fe}$ is converted to $\mathrm{FeO}$ and further to $\mathrm{Fe}_{3} \mathrm{O}_{4}$. At the same time, the $\mathrm{Ni}_{3} \mathrm{Fe}$ alloy phase loses some intensity, and formation of a small amount of $\mathrm{NiFe}_{2} \mathrm{O}_{4}$ spinel cannot be excluded. Diffractions for this spinel would yield shoulders to the $\mathrm{Fe}_{3} \mathrm{O}_{4}$ diffractions, but for this material, they likely remain undetected as the Ni loading in the sample is very small. The $\mathrm{Fe}_{3} \mathrm{O}_{4}$ phase appeared stable under $\mathrm{CO}_{2}$ and also shortly 
thereafter, already under He. However, while still under inert flow, the $\mathrm{Fe}_{3} \mathrm{O}_{4}$ peaks started fading and changed back into $\mathrm{FeO}$ and $\mathrm{Fe}$ diffractions as if again reduced. Simultaneously, the alloy phase diffraction became more intense. A second $\mathrm{CO}_{2}$ period reconverted $\mathrm{FeO}$ and $\mathrm{Fe}$ to $\mathrm{Fe}_{3} \mathrm{O}_{4}$, which then persisted throughout the entire $7 \mathrm{~min}$ of $\mathrm{He}$ flow. At the origin of these observations is carbon, formed during the reduction step and accumulated on the catalyst surface.

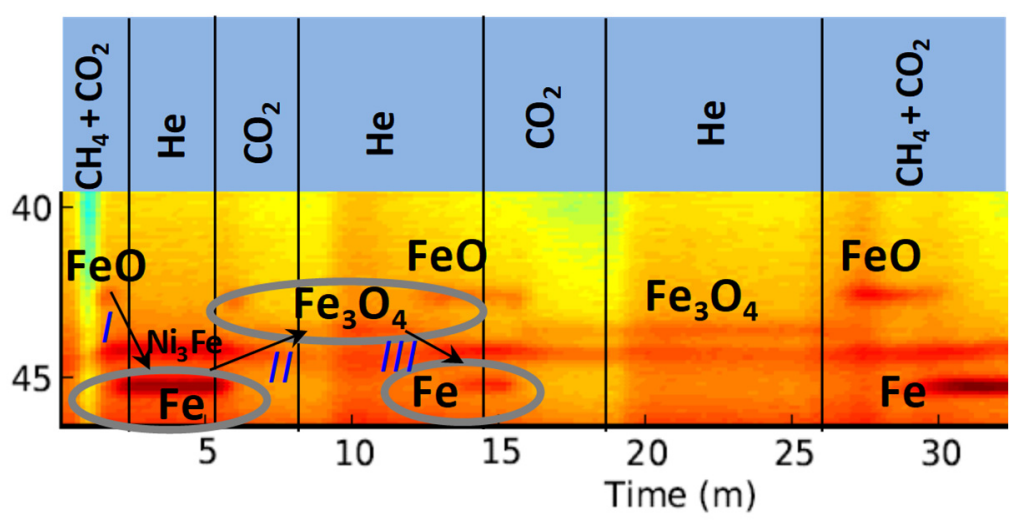

Figure 4. In situ XRD patterns collected from $\mathrm{Ni} / \mathrm{Fe}_{2} \mathrm{O}_{3}-\mathrm{CeO}_{2}$ during reduction/oxidation cycles at $873 \mathrm{~K}$. Transitions are indicated by arrows: FeO reduction (I) and re-oxidation (II), disappearing $\mathrm{Fe}_{3} \mathrm{O}_{4}$ diffraction, re-emergence of first $\mathrm{FeO}$ and then $\mathrm{Fe}$ in $\mathrm{He}$ flow after $\mathrm{CO}_{2}$ re-oxidation (III). Gas environments are indicated above the two-dimensional (2D) patterns [48].

The in situ XRD interpretation is as follows: When introducing pure $\mathrm{CO}_{2}$ for the first time after reduction, it re-oxidizes iron and $\mathrm{CeO}_{2-\delta}$, thereby replenishing their lattice oxygen. The latter then oxidizes the surface carbon. In principle, carbon could also be oxidized directly by $\mathrm{CO}_{2}$ according to the Boudouard reaction. However, this cycling in situ XRD experiment proves that oxidation of carbon deposits by lattice oxygen equally occurs, since even under inert flow, iron oxide is again reduced (Figure 4, step III). Apparently, the first $\mathrm{CO}_{2}$ pulse was not sufficiently long to both re-oxidize the material and remove all carbon from the surface. As a result, after the $\mathrm{CO}_{2}$ pulse, the remaining $\mathrm{C}$ gets removed with the help of lattice oxygen from the $\mathrm{Fe}_{2} \mathrm{O}_{3}-\mathrm{CeO}_{2}$ material, leading to reduction anew even without a reductive atmosphere. The subsequent longer $\mathrm{CO}_{2}$ pulse removes all carbon so that $\mathrm{Fe}$ is permanently oxidized back to $\mathrm{Fe}_{3} \mathrm{O}_{4}$.

The duration of the catalytic activity and hence the extent of carbon formation on the surface depend on the overall oxygen capacity of the material. Usually, coke formed on the catalyst surface is responsible for fouling of the active sites, thereby deactivating the nickel catalyst particles. In order to counter this, the material requires periodic regeneration, which is exactly what the concept of chemical looping is providing, since it comprises cycles of reduction and re-oxidation steps. The refill of the OSM upon re-oxidation is conveniently accompanied by surface carbon removal, which in parallel yields more $\mathrm{CO}$ than the theoretical value which stems from complete oxidation of $\mathrm{Fe}$ to $\mathrm{Fe}_{3} \mathrm{O}_{4}$.

Another example of a catalyst-assisted chemical looping process is steam reforming of methane (CLSRM), which is capable of generating both syngas and hydrogen in its halfcycles [49]. Whereas in the previous example, Ni was taking up the catalyst function, here, $\mathrm{Fe}_{2} \mathrm{O}_{3}$ and/or $\mathrm{CeO}_{2}$ fulfil this role. The used Fe@Ce material with core-shell architecture is key to this process. Using a ceria shell enclosing an iron oxide core as an oxygen carrier combines advantages of ceria and iron oxide: high ion conductivity for the former and high oxygen storage capacity for the latter. The activity of Fe@Ce was assessed in fixed-bed tests and compared to a uniform mix of $\mathrm{Fe}-\mathrm{Ce}$ as a reference. Compared to the mixture, the core-shell Fe@Ce material yielded more syngas and hydrogen, and better selectivity for $\mathrm{CO}$ and methane conversion in the reduction process. The syngas and hydrogen yield of Fe@Ce was an approximately constant value of 16 and $6 \mathrm{mmol} \times \mathrm{g}^{-1}$ compared to 14 
and $5 \mathrm{mmol} \times \mathrm{g}^{-1}$ for the $\mathrm{CeO}_{2}$ and $\mathrm{Fe}_{2} \mathrm{O}_{3}$ mixture. This indicates that the core-shell structure can selectively provide oxygen from the $\mathrm{CeO}_{2}$ shell, which eases the transport of oxygen ions between the core and the shell. Moreover, the selectivity to $\mathrm{CO}$ and the $\mathrm{CH}_{4}$ conversion for the core-shell oxygen carrier further improved for an increasing number of cycles, likely due to the enhancement of the oxygen ion conduction and resulting from the increasing contribution of a $\mathrm{CeFeO}_{3}$ phase. The carbon deposition for $\mathrm{Fe} @ \mathrm{Ce}$ amounted on average to only $29 \%$ of that for $\mathrm{Fe}-\mathrm{Ce}$, leading to higher-quality syngas with a $\mathrm{H}_{2} / \mathrm{CO}$ ratio close to 2 and higher-purity $\mathrm{H}_{2}$. The high resistance against $\mathrm{C}$ accumulation was ascribed to the ceria shell, having excellent oxygen ion conductivity. The latter ensures rapid migration and replenishment of oxygen ions at the surface. In addition, iron metal sites, which activate methane, are scarce on the surface, due to the $\mathrm{CeO}_{2}$ shell, leading to higher carbon resistance.

$\mathrm{CeO}_{2}$ itself is quite active towards methane oxidation through its lattice oxygen, and it has a reasonable capacity for $\mathrm{H}_{2} \mathrm{O}$ or $\mathrm{CO}_{2}$ re-oxidation [50,51]. Oxygen storage in and release from the bulk fluorite lattice are facilitated by its redox couple $\mathrm{Ce}^{4+}$ and $\mathrm{Ce}^{3+}$. In combination with iron oxide, $\mathrm{CeO}_{2}$ can modify and stabilize the structure, making it very suited as a promoter of iron oxide in a chemical looping process. When combining $\mathrm{CeO}_{2}$ with $\mathrm{MeO}_{\mathrm{x}}(\mathrm{Me}=\mathrm{Mn}, \mathrm{Fe}$, or $\mathrm{Cu})$, a mixed oxide was formed, exhibiting higher reducibility than pure $\mathrm{CeO}_{2}[52,53]$. When $\mathrm{CeO}_{2}$ interacts with $\mathrm{Fe}_{2} \mathrm{O}_{3}$, this also leads to enhanced reducibility of $\mathrm{Fe}_{2} \mathrm{O}_{3}$ [54]. Depending on the composition, part of the interaction is established through formation of a mixed oxide, wherein the ceria structure takes up a limited amount of $\mathrm{Fe}^{3+}$ cations. The evolution of the $\mathrm{Fe}_{2} \mathrm{O}_{3}-\mathrm{CeO}_{2}$ structure as a function of composition is shown in Figure 5 [53].

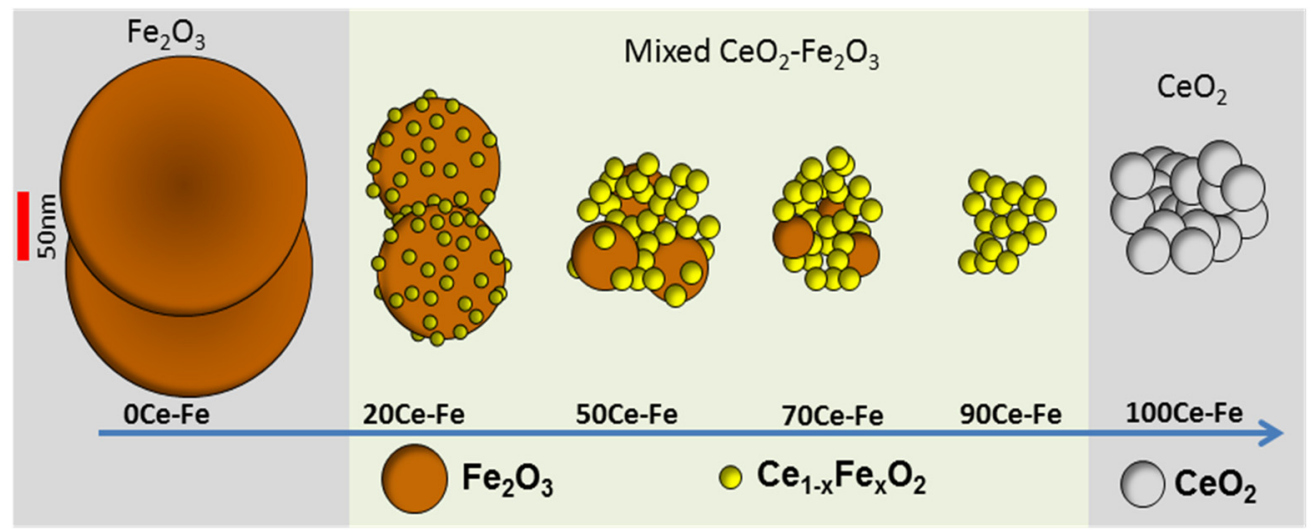

Figure 5. Scheme of a series of mixed $\mathrm{CeO}_{2}-\mathrm{Fe}_{2} \mathrm{O}_{3}$ samples, composed on the basis of inductively coupled plasma (ICP) composition, XRD, STEM, EDX and EELS analysis [53].

The question is how much Fe can actually be incorporated into ceria for different compound ratios? The $\mathrm{CeO}_{2}$ lattice parameter for the entire range of mixed oxide materials (Figure 6) levels off beyond $10 \mathrm{wt} \% \mathrm{Fe}_{2} \mathrm{O}_{3}-\mathrm{CeO}_{2}$ [54]. In addition, the XRD pattern for $10 \mathrm{wt} \% \mathrm{Fe}_{2} \mathrm{O}_{3}-\mathrm{CeO}_{2}$ shows no $\mathrm{Fe}_{2} \mathrm{O}_{3}$ contribution, meaning no separate crystalline phase is present, unless it is nanosized. In order to assess this maximal Fe amount in the lattice, the Ce-K edge Extended X-Ray Absorption Fine Structure (EXAFS) signal for $10 \mathrm{wt} \%$ $\mathrm{Fe}_{2} \mathrm{O}_{3}-\mathrm{CeO}_{2}$ was recorded and fitted. Two models were compared for the fit: one for the pure $\mathrm{CeO}_{2}$ fluorite structure and another one with a Fe-doped $\mathrm{CeO}_{2}$ structure or solid solution, denoted as $\mathrm{Ce}_{1-\mathrm{x}} \mathrm{Fe}_{\mathrm{x}} \mathrm{O}_{2-\mathrm{x}}$, where $\mathrm{x}$ denotes the incorporated amount of $\mathrm{Fe}$, taken as a parameter in the fit. A value of $\mathrm{x}=0.21 \pm 0.08$ yielded the best correspondence (Figure 7), meaning that $21 \%$ of the Ce atoms in $\mathrm{CeO}_{2}$ are substituted by Fe. For $10 \mathrm{wt} \%$ $\mathrm{Fe}_{2} \mathrm{O}_{3}-\mathrm{CeO}_{2}$, this number indicates that $85 \%$ of the $\mathrm{Fe}$ forms a solid solution with ceria as $\mathrm{Ce}_{1-x} \mathrm{Fe}_{\mathrm{x}} \mathrm{O}_{2-\mathrm{x}}$. As the ceria lattice parameter does not change beyond $10 \mathrm{wt} \% \mathrm{Fe}_{2} \mathrm{O}_{3}$, it can be safely assumed that, e.g., in $80 \mathrm{wt} \% \mathrm{Fe}_{2} \mathrm{O}_{3}-\mathrm{CeO}_{2}$, the same $21 \mathrm{~mol} \%$ of $\mathrm{Ce}$ is exchanged for $\mathrm{Fe}$, which of course represents only a small fraction of all $\mathrm{Fe}$ in $80 \mathrm{wt} \% \mathrm{Fe}_{2} \mathrm{O}_{3}-\mathrm{CeO}_{2}$. 


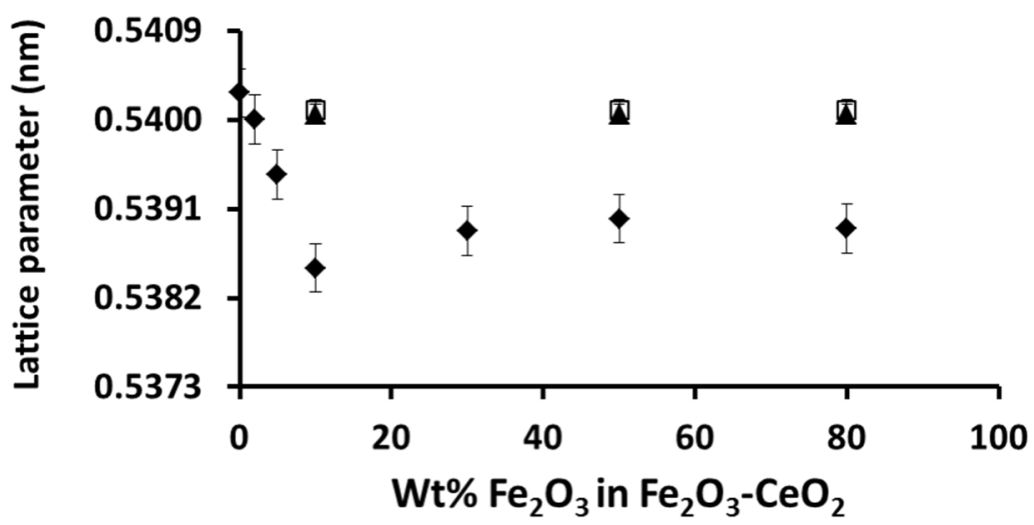

Figure 6. Unit cell parameters for ceria in a series of $x \mathrm{wt} \% \mathrm{Fe}_{2} \mathrm{O}_{3}-\mathrm{CeO}_{2}$ with variable $\mathrm{Fe}_{2} \mathrm{O}_{3}$ loading (diamond) as prepared, (triangle) $\mathrm{CO}_{2}$-reoxidation and (square) $\mathrm{O}_{2}$-reoxidation states. Error bars represent standard deviation (68\% confidence interval) [54].

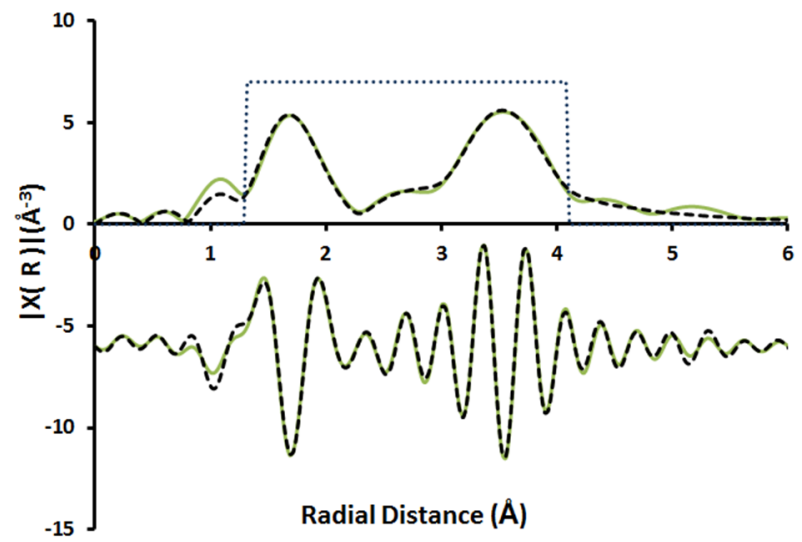

Figure 7. Fourier-transformed $\mathrm{k}^{2}$-weighted Ce-K edge Extended X-Ray Absorption Fine Structure (EXAFS) spectrum for $10 \mathrm{wt} \% \mathrm{Fe}_{2} \mathrm{O}_{3}-\mathrm{CeO}_{2}$ and modelling fit (dashed line), with an Fe incorporated $\mathrm{CeO}_{2}$ model $\mathrm{Ce}_{1-x} \mathrm{Fe}_{\mathrm{x}} \mathrm{O}_{2-\mathrm{x}}$, wherein $\mathrm{x}=0.21$. Upper part: Fourier transforms (FT) modulus, lower part: imaginary $\left.\operatorname{Im}\left[\mathrm{FT}\left[\mathrm{k}^{2} \chi(\mathrm{R})\right]\right)\right]$. Dotted rectangle: window fitting range. No phase correction was used. (-) EXAFS signal of $10 \mathrm{wt} \% \mathrm{Fe}_{2} \mathrm{O}_{3}-\mathrm{CeO}_{2},(---)$ fit and (...) fitting window [54].

To identify the structural properties of Fe-rich material at the far end of the $\mathrm{Fe}_{2} \mathrm{O}_{3}-$ $\mathrm{CeO}_{2}$ mixing range, $80 \mathrm{wt} \% \mathrm{Fe}_{2} \mathrm{O}_{3}-\mathrm{CeO}_{2}$ was also investigated. Figure $8 \mathrm{a}$ shows a high angle annular dark field scanning TEM (HAADF-STEM) image for $80 \mathrm{wt} \% \mathrm{Fe}_{2} \mathrm{O}_{3}-\mathrm{CeO}_{2}$, in which two types of particles are discerned: small ones, decorating larger ones. According to Electron energy loss spectroscopy (EELS) maps, the former are $\mathrm{CeO}_{2}$ (Figure 8b), while the latter pertain to $\mathrm{Fe}_{2} \mathrm{O}_{3}(\sim 50 \mathrm{~nm})$. After 100 cycles of chemical looping, the particles are strongly agglomerated, and show considerably larger size (Figure 8c). Nevertheless, even in this sintered condition, the decorative configuration of ceria surrounding iron oxide persists (Figure $8 \mathrm{~d}$ ).

For the above-mentioned $\mathrm{Fe}_{2} \mathrm{O}_{3}-\mathrm{CeO}_{2}$ materials, the crystalline phases, sizes and morphological changes, before and after cycled operation (as in chemical looping), were determined using (S)TEM, XAS (X-ray absorption spectroscopy) and XRD. Next to sintering, two other types of deactivation were identified: first, Fe can get extracted from the $\mathrm{Ce}_{1-x} \mathrm{Fe}_{\mathrm{x}} \mathrm{O}_{2}$ solid solution, and second, a perovskite $\left(\mathrm{CeFeO}_{3}\right)$ can be formed. The extraction of Fe from the solid solution can proceed quite fast, leading to less reducibility for $\mathrm{CeO}_{2}$. However, the extraction sets free more Fe, which in turn can add to the overall oxygen storage capacity. For the latter, perovskite formation is only negative, as $\mathrm{CeFeO}_{3}$ is not reducible below $800{ }^{\circ} \mathrm{C}$. The slowest deactivation process is undoubtedly sintering, 
occurring throughout operation. Because it steers crystallite sizes to grow, longer diffusion times are induced for oxygen to move from the bulk to the surface. So, a given reduction time will gradually lead to a lower degree of reduction reached, hence less $\mathrm{CO}$ yield upon re-oxidation.

Which of these deactivation types dominates is dependent on the material composition. Iron-rich samples are mostly prone to sintering as a predominant mechanism, while Fe extraction is less important based on composition. Similarly, there could be some perovskite forming, but its contribution to the overall composition will not affect the productivity. For ceria-rich samples, all three types of deactivation need to be taken into account. Looking at the $\mathrm{CO}$ yield, the best performing material for extended use in chemical looping is $80 \mathrm{wt} \%$ $\mathrm{Fe}_{2} \mathrm{O}_{3}-\mathrm{CeO}_{2}$. In this sample, sintering as a main deactivation mechanism is controlled by decorating $\mathrm{Fe}_{2} \mathrm{O}_{3}$ with $\mathrm{CeO}_{2}$ nanoparticles.

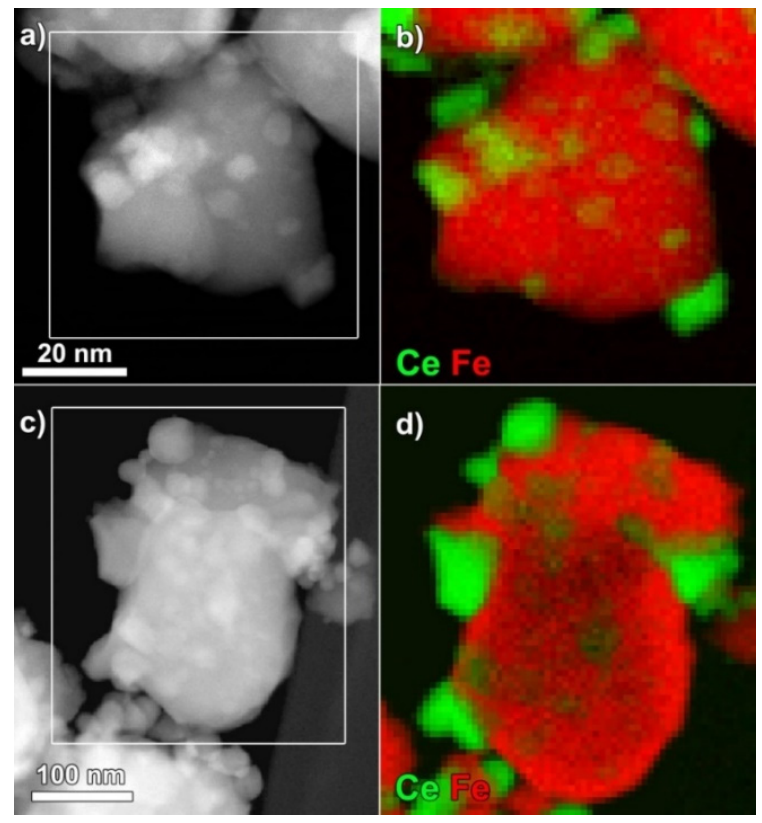

Figure 8. (a) Image of calcined $80 \mathrm{wt} \% \mathrm{Fe}_{2} \mathrm{O}_{3}-\mathrm{CeO}_{2}$ via high angle annular dark field scanning TEM (HAADF -STEM), (b) corresponding EELS map for Fe and Ce, (c) image for cycled $80 \mathrm{wt} \%$ $\mathrm{Fe}_{2} \mathrm{O}_{3}-\mathrm{CeO}_{2}\left(100 \mathrm{H}_{2}-\mathrm{CO}_{2}\right.$ redox cycles $)$ and (d) corresponding EELS map for Fe and Ce [54].

When looking for materials that combine a catalytic (A) with an oxygen storage function ( $\mathrm{Fe}$ ), spinel ferrites with composition $\mathrm{AFe}_{2} \mathrm{O}_{4}$ also come into the picture. Unlike modifying a Fe-based material by adding a catalyst, ferrite-based materials are prepared via co-precipitation of all elements. Among a series of chemical looping experiments with Me-ferrites $(\mathrm{Me}=\mathrm{Ni}, \mathrm{Co}, \mathrm{Cu}, \mathrm{Mn}, \mathrm{Zn})$, interesting $\mathrm{CH}_{4}$ dry reforming activity and redox stability were found for $\mathrm{NiFe}_{2} \mathrm{O}_{4}$ and $\mathrm{CoFe}_{2} \mathrm{O}_{4}$. As biomass conversion increases the availability of alcohols as possible feedstock, these two bifunctional materials were then tested for chemical looping alcohol reforming with ethanol and methanol into syngas. $\mathrm{NiFe}_{2} \mathrm{O}_{4}-\mathrm{CeZrO}_{2}$ and $\mathrm{CoFe}_{2} \mathrm{O}_{4}-\mathrm{CeZrO}_{2}$ were studied by Dharanipragada et al. [55] as bifunctional materials for catalyst-assisted chemical looping dry reforming (CCDR) with either a pure methanol feed or a mixed ethanol-water feed (1:1 molar ratio). The alcohols are fed in the chemical looping reduction step, where they are converted over the catalyst to $\mathrm{CO}$ and $\mathrm{H}_{2}$, aside from some $\mathrm{CH}_{4}$ in case water is co-fed. These gases reduce the oxygen storage component of the material, so that in the subsequent re-oxidation step, its regeneration with $\mathrm{CO}_{2}$ produces $\mathrm{CO}$ (Figure 9). 
(a)

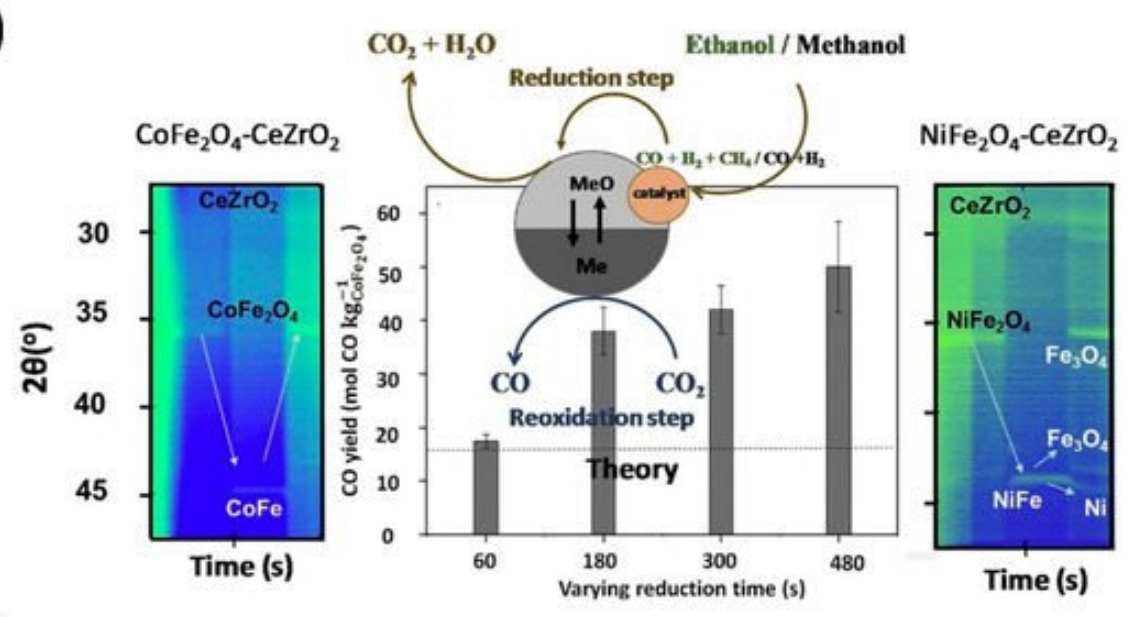

(b)

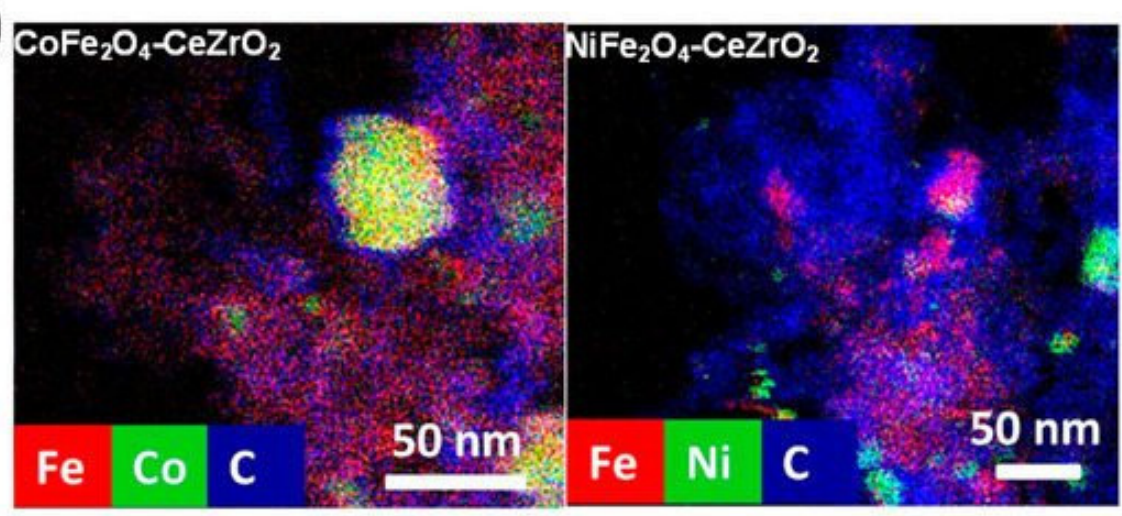

Figure 9. Bifunctional Co- and Ni-ferrites modified with $\mathrm{CeZrO}_{2}$ for chemical looping dry reforming with alcohols as feed: (a) Transformation of solid and gaseous phases, (b) elemental maps of Co, Ni, $\mathrm{Fe}$ and $\mathrm{C}$ in $20 \mathrm{wt} \% \mathrm{CoFe}_{2} \mathrm{O}_{4}-\mathrm{CeZrO}_{2}$ and $\mathrm{NiFe}_{2} \mathrm{O}_{4}-\mathrm{CeZrO}_{2}$ after methanol redox cycles [55].

Material with low $\mathrm{CoFe}_{2} \mathrm{O}_{4}$ content $(20 \mathrm{wt} \%)$ presented good redox activity and stability, while the $80 \mathrm{wt} \% \mathrm{CoFe}_{2} \mathrm{O}_{4}$-loaded material deactivated, due to $\mathrm{Co}$ and $\mathrm{Fe}_{3} \mathrm{O}_{4}$ segregation from the ferrite. As for the Ni-ferrite- $\mathrm{CeZrO}_{2}$ materials, these were all prone to sintering and phase segregation, which turned out to be irreversible. Carbon formation was observed in the methanol-based CCDR process for both types of ferrite materials, but far more over the Ni-ferrite (Figure 9b), demonstrating a significantly lower carbon resistance. As mentioned before, the presence of carbon deposits can enhance the $\mathrm{CO}$ yield upon re-oxidation with $\mathrm{CO}_{2}$, raising the yield above the theoretical value, as was verified experimentally (Figure 9a).

Materials, having dual functions of catalyst and oxygen storage, perform well in catalyst-assisted chemical looping. Based on the latter behavior, autothermal catalystassisted chemical looping with the same materials has been advanced as a novel strategy for $\mathrm{CO}$ production from $\mathrm{CH}_{4}$ and $\mathrm{CO}_{2}$ [56]. The process is built on two approaches, each with a dedicated material: $1 / \mathrm{Fe}_{3} \mathrm{O}_{4}$ for $\mathrm{CO}$ production by chemical looping and 2/a Nibased catalyst for autothermal catalytic conversion of $\mathrm{CH}_{4}, \mathrm{CO}_{2}$ and $\mathrm{O}_{2}$ to syngas. The design of the process allows to convert three times as much $\mathrm{CO}_{2}$ than is produced in the reduction. By feeding $\mathrm{CH}_{4}, \mathrm{CO}_{2}$ and, in addition, some $\mathrm{O}_{2}$, simultaneously to the chemical looping reactor, the endothermicity of dry reforming is overcome. According to thermodynamic analysis, a molar ratio of $\mathrm{CH}_{4} / \mathrm{O}_{2}$ equal to 0.3 or 0.5 allows to achieve autothermal operation at 873 and $1023 \mathrm{~K}$, respectively. If the ratio of reducing $\left(\mathrm{CO}+\mathrm{H}_{2}\right)$ to oxidizing $\left(\mathrm{H}_{2} \mathrm{O}+\mathrm{CO}_{2}\right)$ gases in the feed during the reduction is above 2 and the temperature over $873 \mathrm{~K}$, a high degree of $\mathrm{Fe}_{3} \mathrm{O}_{4}$ reduction can be obtained. To prove this concept, a multifunctional $9 \mathrm{wt} \% \mathrm{NiO}-16 \mathrm{wt} \% \mathrm{Fe}_{2} \mathrm{O}_{3} / \mathrm{MgAl}_{2} \mathrm{O}_{4}$ was synthesized to test the 
process. In the reducing step, $\mathrm{CH}_{4}+\mathrm{CO}_{2}+\mathrm{O}_{2}$ (molar ratio of 1:1:0.5) is converted by the $\mathrm{NiO}$ catalyst into a $\mathrm{CO}$ and $\mathrm{H}_{2}$ mixture, which reduces $\mathrm{Fe}_{3} \mathrm{O}_{4}$, producing $\mathrm{CO}_{2}$ and $\mathrm{H}_{2} \mathrm{O}$. At the same time, reduction induces interaction between $\mathrm{Ni}$ with $\mathrm{Fe}$ so that a $\mathrm{Ni}-\mathrm{Fe}$ alloy is formed. Subsequent $\mathrm{CO}_{2}$ feeding leads to decomposition of the alloy into $\mathrm{Ni}$ and $\mathrm{Fe}_{3} \mathrm{O}_{4}$, in parallel to $\mathrm{CO}$ production by re-oxidation of reduced iron oxide. Although deactivation occurs for all materials during extended operation at $1023 \mathrm{~K}$, principally due to sintering according to TEM imaging, the latter seems to be limited mainly to the first few cycles, after which operation stabilizes [56].

Recently, calcium ferrite $\mathrm{Ca}_{2} \mathrm{Fe}_{2} \mathrm{O}_{5}$ has been explored as an oxygen carrier for chemical looping and this material can reportedly provide a higher steam conversion to hydrogen than $\mathrm{Fe}_{2} \mathrm{O}_{3}$ [57-60]. However, the system has limited reactivity with $\mathrm{CH}_{4}$. High-purity $\mathrm{H}_{2}$ can however be produced from $\mathrm{CH}_{4}$ using approaches based on catalyst-assisted chemical looping. Hosseini et al. demonstrated that doping calcium ferrite with Ni or $\mathrm{Cu}$ significantly enhances their redox performance [61]. It was found that adding $\mathrm{Cu}$ to $\mathrm{Ca}_{2} \mathrm{Fe}_{2} \mathrm{O}_{5}$ increases the reducibility with $\mathrm{CH}_{4}$ and yields stable $\mathrm{H}_{2}$ production. They also showed that copper has high incorporation mobility in the material during air reoxidation, which provides an effective way to control the $\mathrm{Cu}$ nanoparticles' dispersion. Such exsolution and re-incorporation of copper is key to maintain the high reactivity. In contrast to $\mathrm{Cu}$, Ni-doped calcium ferrite did not provide stability in $\mathrm{H}_{2}$ production. In situ XRD and STEM-EDS identified that during material reduction, a Ni-Fe alloy formed, which may lead to gradual sintering of Ni particles [61].

The same strategy of reversible exsolution to control dispersion of metallic nanoparticles was used by Carrillo et al. [62-64]. La0.6Sr0.4 $\mathrm{Cr}_{0.8} \mathrm{Co}_{0.2} \mathrm{O}_{3}$ (LSCC) was selected as an oxygen carrier for $\mathrm{CO}_{2}$ conversion into $\mathrm{CO}$. The perovskite was promoted with $\mathrm{Co}$ nanoparticles for the methane reforming reaction. The $30 \mathrm{~nm}$ Co nanoparticles exhibited microstructural stability and uniform dispersion during 28 redox cycles at $900{ }^{\circ} \mathrm{C}$.

Ethylene makes an important building block and valuable commodity chemical for many compounds such as oxygenates, polymers and other chemical intermediates. It is mainly produced by steam cracking, for which ethane oxidative dehydrogenation (ODH) could be an alternative [65-67]. Herein, hydrogen is oxidized with oxygen, so that the ethane conversion equilibrium is shifted, and the overall reaction becomes exothermic. However, ethane ODH faces some practical challenges: (i) potential safety hazards arise when cofeeding oxygen and ethane, requiring dilution with inert gas, (ii) separating air for oxygen generation is capital- and energy-intensive and (iii) ethylene selectivity is reported to be limited at high single-pass ethane conversions.

To overcome these challenges, it was proposed by Gao et al. [68] to use oxidative dehydrogenation in a chemical looping manner (CL-ODH) (see Figure 10) [69]. In this concept, CL-ODH resembles chemical looping redox processes, like oxygen uncoupling (CLOU) [70] and methane partial oxidation [71]. In CL-ODH, oxygen is delivered from the lattice of a redox catalyst to convert ethane to ethylene and water. The ODH drawbacks are then circumvented as air separation is not required, which removes the safety issues about mixing ethane with oxygen. Based on process simulations, the CL-ODH process leads to a reduction of $\mathrm{CO}_{2}$ emissions by up to $82 \%$ when compared to steam cracking, and less energy consumption. $\mathrm{Mg}_{6} \mathrm{MnO}_{8}$ promoted with sodium tungstate $\left(\mathrm{Na}_{2} \mathrm{WO}_{4}\right)$ was shown to be an effective redox catalyst for CL-ODH. In order to achieve high ethylene selectivity, both $\mathrm{Na}$ and $\mathrm{W}$ were found to be necessary to form $\mathrm{Na}_{2} \mathrm{WO}_{4}$. With a $\mathrm{Na}: \mathrm{W}$ ratio lower than 2:1, additional mixed tungsten oxide phases are formed, which leads to less ethylene selectivity. 


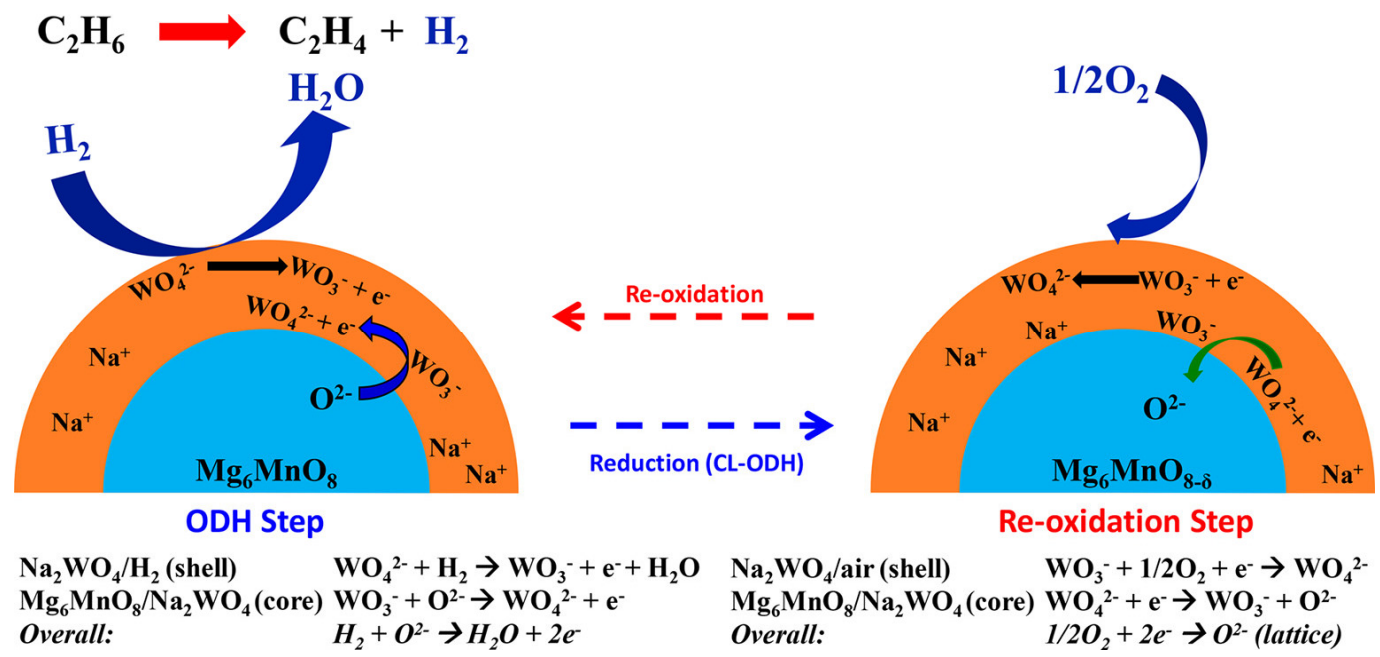

Figure 10. Scheme for oxidative dehydrogenation in a chemical looping manner of ethane over $\mathrm{Mg}_{6} \mathrm{MnO}_{8}$ redox catalysts, promoted with $\mathrm{NaW}$ (In each step, reduction/oxidation of $\mathrm{Mn}$ cations in the $\mathrm{Mg}_{6} \mathrm{MnO}_{8}$ core balance the electrons) [69].

An interesting process for methane conversion from stranded natural gas to valuable liquid aromatic compounds is provided by dehydroaromatization (DHA), a reaction which is limited by thermodynamics. Brady et al. [72] have presented a way to overcome this limitation by placing DHA in a chemical looping frame to enable reactive separation of $\mathrm{H}_{2}$ from the DHA products. They proposed a four-step cycle to achieve this: DHA over a Mo/H-ZSM- 5 catalyst, removal of $\mathrm{H}_{2}, \mathrm{Fe}_{3} \mathrm{O}_{4} / \mathrm{FeO}$ redox pair regeneration and water removal on H-ZSM-5. Each of these steps was evaluated individually, to assess the process feasibility, and the results indicate that the proposed process allows to achieve an aromatics yield of over $40 \%$.

It is still a challenge to control selectivity in partial oxidation of methane by lattice oxygen of metal oxides. Zvang et al. present the finding that distortion of $\mathrm{FeO}_{6}$ octahedra in $\mathrm{La}_{1-x} \mathrm{Ce}_{x} \mathrm{FeO}_{3}$ perovskites positively affects the surface oxygen exchange capability and mobility of bulk oxygen [73]. The distortion of the $\mathrm{FeO}_{6}$ octahedra can be promoted due to the difference between $\mathrm{Ce}-\mathrm{O}$ and $\mathrm{La}-\mathrm{O}$ bond lengths. The authors achieve a syngas productivity during the reduction cycle of 3 to up to 8 times higher than with $\mathrm{LaFeO}_{3}$ and $\mathrm{CeFeO}_{3}$. At the same time, a $\mathrm{CO}_{2}$ conversion of $92 \%$ was achieved during the reoxidation cycle. Adjusting the octahedral distortion in these perovskites hence provides a means to modulate the active lattice oxygen, which affects their performance in chemical looping processes.

Catalyst-assisted chemical looping processes can also aim at $\mathrm{N}_{2}$ activation and conversion, wherein hydrogen species play a role, as highlighted in a recent publication [74]. Herein, ammonia is advanced as a promising "carbon-free" energy carrier, but its current industrial synthesis requires severe conditions. If it could be produced at lower temperatures and pressures, this would drastically increase its prospects as an energy carrier and chemical alike. Both alkali and alkaline earth metal imides can operate as nitrogen carriers and produce ammonia via a chemical looping process, operating at atmospheric pressure and $100{ }^{\circ} \mathrm{C}$, according to Gao et al. [74]. The first step fixes nitrogen into imides by reduction with alkali or alkaline earth metal hydrides. The second step hydrogenates the imides to produce $\mathrm{NH}_{3}$, thereby regenerating the metal hydrides. Throughout this process, the hydrogen oxidation state switches between -1 (hydride), $0\left(\mathrm{H}_{2}\right)$ and +1 (imide and $\mathrm{NH}_{3}$ ) (see Figure 11). This scheme for $\mathrm{NH}_{3}$ production is mediated by BaNH and catalyzed by $\mathrm{Ni}$, making it another example of a catalyst-assisted chemical looping process. 


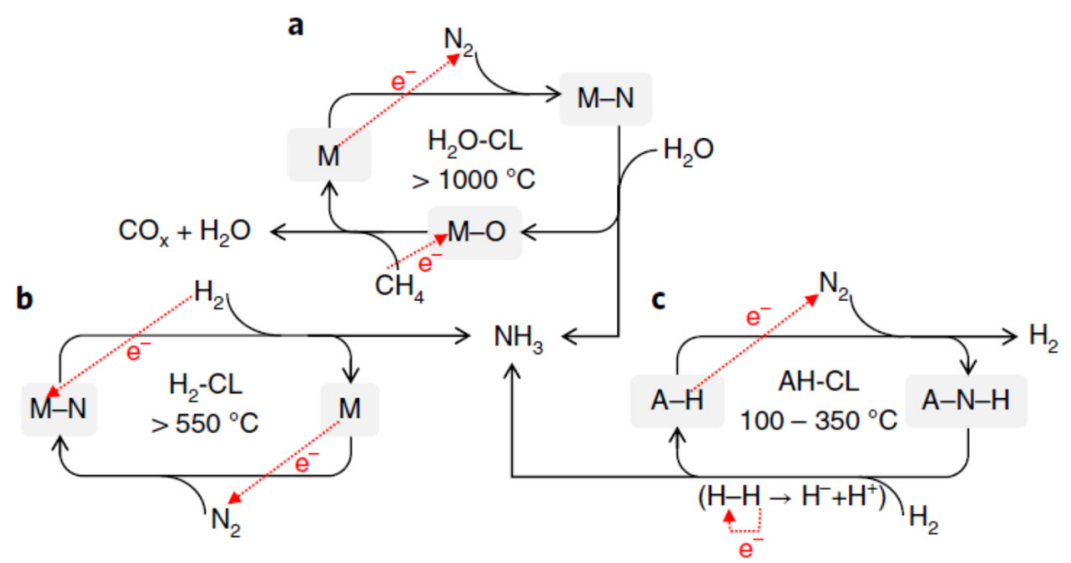

Figure 11. Ammonia synthesis by catalyst-assisted chemical looping: (a) $\mathrm{H}_{2} \mathrm{O}-\mathrm{CL}$ process, (b) $\mathrm{H}_{2}-\mathrm{CL}$ process, (c) AH-CL process. Metal and the corresponding metal nitride and oxide are represented by $\mathrm{M}, \mathrm{M}-\mathrm{N}$ and $\mathrm{M}-\mathrm{O}$, respectively. A-H and A-N-H stand for alkali or alkaline earth metal hydride and imide, respectively [74].

Figure 12 presents the rates of ammonia production in chemical looping and catalystassisted processes using $\mathrm{Ni}$. The loop with neat $\mathrm{LiH} / \mathrm{Li}_{2} \mathrm{NH}$ as a mediator produces ammonia at a rate of $\sim 100 \mu \mathrm{mol} \mathrm{NH} 3 \mathrm{~g}^{-1} \mathrm{LiH} \mathrm{h}^{-1}$ at $350{ }^{\circ} \mathrm{C}$, while the $50 \% \mathrm{Ni}-\mathrm{LiH}$ sample achieves $1530 \mu \mathrm{mol} \mathrm{NH} \mathrm{g}^{-1} \mathrm{LiH} \mathrm{h}^{-1}$ at $300^{\circ} \mathrm{C}$. At that same temperature, neat $\mathrm{BaH}_{2} / \mathrm{BaNH}$ used in a loop produces $200 \mu \mathrm{mol} \mathrm{NH} 3 \mathrm{~g}-1 \mathrm{BaH}_{2} \mathrm{~h}^{-1}$, though a much higher value of $3120 \mu \mathrm{mol} \mathrm{NH} \mathrm{g}^{-1} \mathrm{BaH}_{2} \mathrm{~h}^{-1}$ is accomplished by $50 \% \mathrm{Ni}-\mathrm{BaH}_{2}$. Even $5 \% \mathrm{Ni}$ addition can boost the $\mathrm{NH}_{3}$ production rate from $\mathrm{BaH}_{2}-\mathrm{CL}$ six-fold.

a

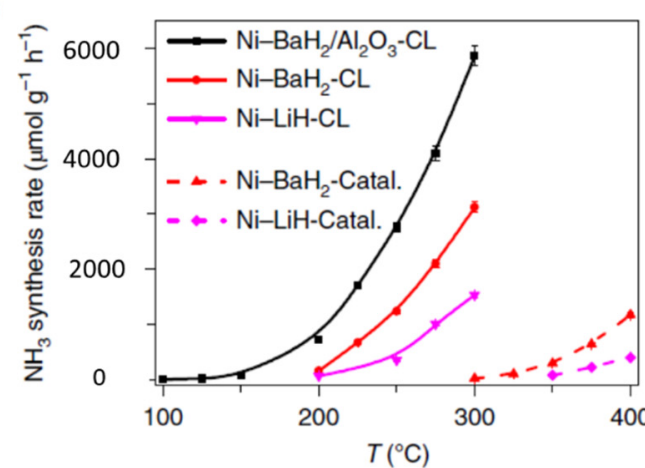

b

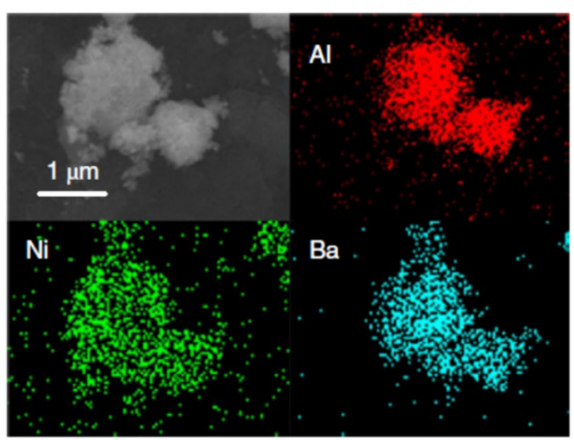

Figure 12. $\mathrm{Ni}-\mathrm{BaH}_{2}$ and $\mathrm{Ni}-\mathrm{LiH}$ performance in $\mathrm{NH}_{3}$ production. (a) Temperature-dependent production rates in chemical looping (CL) and thermo-catalytic processes (Catal). (b) Microscope images and elemental maps of spent $\mathrm{Ni}-\mathrm{BaH}_{2} / \mathrm{Al}_{2} \mathrm{O}_{3}$ [74].

\section{Combined Chemical Looping}

Integrating several processes into one overall scheme of combined chemical looping (CCL) has multiple advantages. As an example, sorption-enhanced steam reforming (SESR), advanced by Lyon and Cole [75], lowers the economic and environmental barriers that accompany conventional reforming, while offering high efficiency, autothermal operation, together with inherent separation of pure $\mathrm{H}_{2}$ and $\mathrm{CO}_{2}$ (Figure 13a) [19,76,77]. The exothermicity of the oxygen carrier re-oxidation supplies energy for the endothermic reaction of sorbent regeneration, so that heat requirements are minimal. According to thermodynamic calculations, a decrease of up to $55 \%$ in energy demand is possible compared to the conventional steam reforming process [78]. Production of high-purity $\mathrm{H}_{2}$ and pure $\mathrm{CO}_{2}$ as by-products, with a high degree of autothermicity, was equally demonstrated by Lemonidou's group. They mixed $\mathrm{NiO} / \mathrm{ZrO}_{2}$ and $\mathrm{CaO} / \mathrm{CaZrO}$ with $\mathrm{NiO} / \mathrm{CaO}=0.5$ in a 
fixed-bed reactor [79-81] to run the process, which combines catalytic steam reforming, calcium chemical looping and chemical looping combustion. Figure 14 displays the reformate gas composition on dry basis during the reduction/reforming step. The $\mathrm{H}_{2}$ yield during combined chemical looping steam reforming lies very close to equilibrium. As more and more product $\mathrm{CO}_{2}$ is taken up by the sorbent, the more the concentrations of $\mathrm{CO}, \mathrm{CO}_{2}$ and $\mathrm{CH}_{4}$ start to increase at the expense of $\mathrm{H}_{2}$ production (BT: breakthrough). When the sorbent is completely saturated (Post-BT: post-breakthrough), the capture of $\mathrm{CO}_{2}$ stops, and the outlet gas composition equals the one for conventional steam reforming at these conditions. This is the time for switching the gas feed to air in order to re-oxidize $\mathrm{Ni}$ and release the $\mathrm{CO}_{2}$ from the sorbent. The temperature profile and $\mathrm{CO}_{2}$ release during this re-oxidation-calcination stage are depicted in Figure 14c, along with a picture where the measuring positions of temperature are marked. No additional heating was applied after introduction of air, as there was sufficient heat stemming from $\mathrm{Ni}$ re-oxidation to raise the temperature of the reactor from 650 to $\sim 800^{\circ} \mathrm{C}$ (Figure 14c). The latter then facilitated the calcination of the sorbent, as evidenced by the $\mathrm{CO}_{2}$ production. When the Ni oxidation comes to an end, the reactor temperature starts to drop with a concomitant decline in the $\mathrm{CO}_{2}$ formation rate. In a practical application, so the authors remark, the heat from $\mathrm{Ni}$ re-oxidation could even be better utilized if materials were to be moved to another regeneration reactor, where they could be kept at high temperature.

(a)

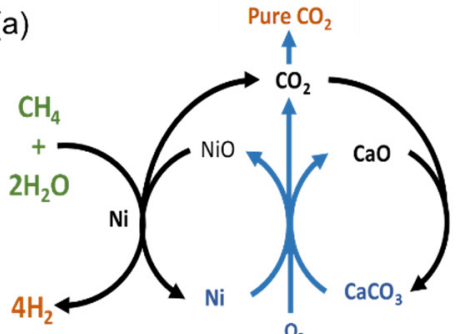

(b)

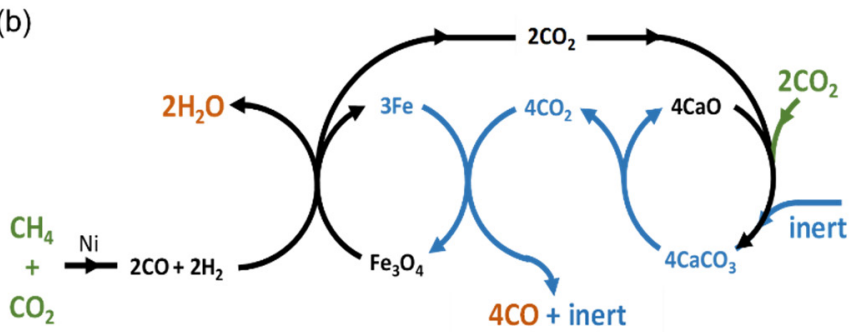

Figure 13. Schemes of combined chemical looping processes: (a) Sorption-enhanced chemical looping reforming of $\mathrm{CH}_{4}$, black arrows: $\mathrm{NiO}$ reduction, $\mathrm{H}_{2}$ production by $\mathrm{CH}_{4}$ reforming and water gas shift over $\mathrm{Ni}$ catalyst, carbonation, blue arrows: Ni oxidation, decarbonation. (b) Super-dry chemical looping reforming of $\mathrm{CH}_{4}$, black arrows: $\mathrm{CO}_{2}$ reforming over $\mathrm{Ni}$ catalyst, $\mathrm{FeO}_{x}$ reduction, carbonation, blue arrows: decarbonation, $\mathrm{CO}$ production by Fe oxidation.
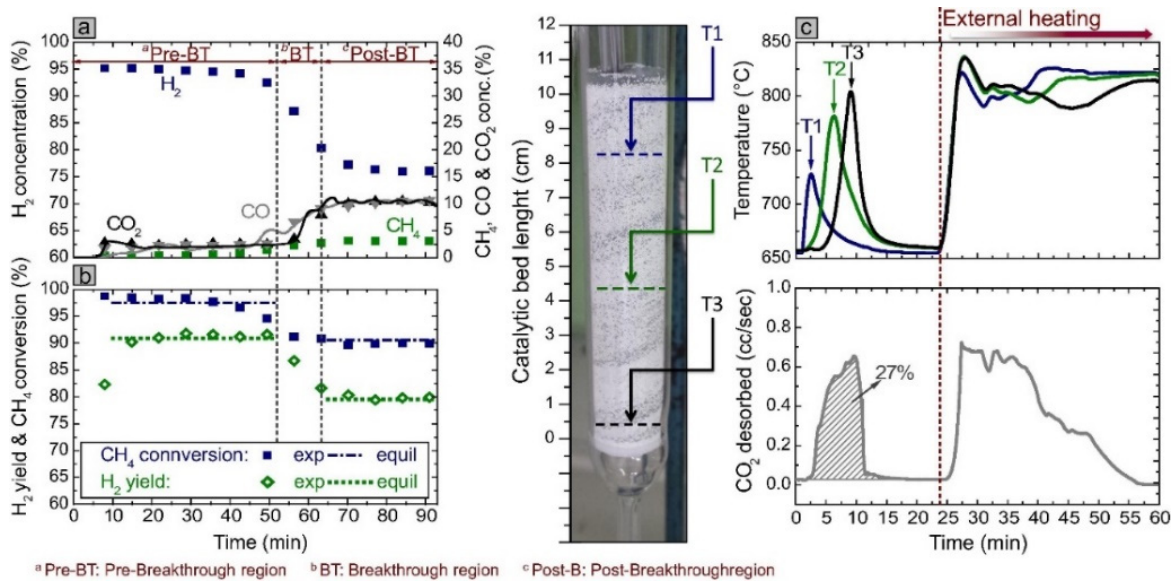

Figure 14. (a) Outlet concentrations, and (b) yield of $\mathrm{H}_{2}$ and $\mathrm{CH}_{4}$ conversion versus time during reduction-steam reforming-carbonation. (c) $\mathrm{CO}_{2}$ formation and temperature profiles versus time during re-oxidation/calcination (reduction-reforming-carbonation: $\mathrm{T}=650^{\circ} \mathrm{C}$, Steam/Carbon ratio $=3, \mathrm{NiO} / \mathrm{CaO}$ molar ratio $=0.5, \mathrm{GHSV}=250 \mathrm{~h}^{-1} ; \mathrm{T}$ during regeneration: $650 \rightarrow 800^{\circ} \mathrm{C}$, air flow, GHSV $\left.=430 \mathrm{~h}^{-1}\right)[80]$. 
As mentioned above, the catalytic reaction of $\mathrm{CH}_{4}$ with $\mathrm{CO}_{2}$ or methane dry reforming (DRM) also benefits from the chemical looping concept. Recently, it was intensified in super-dry reforming (SDR), a process designed for intensified $\mathrm{CO}$ production from $\mathrm{CH}_{4}$ and $\mathrm{CO}_{2}$ [38,82]. Three different materials are needed for this process, each with a particular function: $\mathrm{CaO} / \mathrm{Al}_{2} \mathrm{O}_{3}$ as a $\mathrm{CO}_{2}$ sorbent, $\mathrm{Fe}_{2} \mathrm{O}_{3} / \mathrm{MgAl}_{2} \mathrm{O}_{4}$ to transfer oxygen and $\mathrm{Ni} / \mathrm{MgAl}_{2} \mathrm{O}_{4}$ as a $\mathrm{CH}_{4}$ reforming catalyst, complemented with $\mathrm{CH}_{4}$ and $\mathrm{CO}_{2}$ in a 1:3 ratio (Figure 13b). Here, the exothermicity of $\mathrm{CaCO}_{3}$ formation is coupled to two endothermic processes, $\mathrm{CH}_{4}$ reforming and $\mathrm{Fe}_{3} \mathrm{O}_{4}$ reduction, whereby the energy requirement is looped. The isothermal connection between these three processes results in higher $\mathrm{CO}$ production than with conventional dry reforming.

The most important asset of the calcium looping and methane reforming process as proposed lies in merging the capture of $\mathrm{CO}_{2}$ and its subsequent conversion inclusively in one combined process [83]. Figure 15a illustrates such operation, operating with a CaO-Ni multifunctional sorbent-catalyst. In the $\mathrm{CO}_{2}$ capture step, the $\mathrm{CaO}$ component selectively adsorbs $\mathrm{CO}_{2}$ from the feed stream and stores it as $\mathrm{CaCO}_{3}$.

In the $\mathrm{CO}_{2}$ conversion and $\mathrm{CH}_{4}$ reforming step, $\mathrm{CaCO}$ dissociates to release $\mathrm{CO}_{2}$, which is used in situ for reforming of $\mathrm{CH}_{4}$ on the Ni catalyst, so that syngas is produced. Hereafter, the material is back in its initial state, all set for a new cycle. An essential benefit of this process is that it can use feedstocks with any composition of $\mathrm{CO}_{2}$-containing gas to react with $\mathrm{CH}_{4}$, in particular flue gases with a $\mathrm{CO}_{2}$ content of up to $20 \mathrm{vol} \%$. The integration of $\mathrm{CO}_{2}$ capture and conversion in one process lowers the overall energy penalty by the improved process heat management and by taking out $\mathrm{CO}_{2}$ transport from emission point to utilization site.
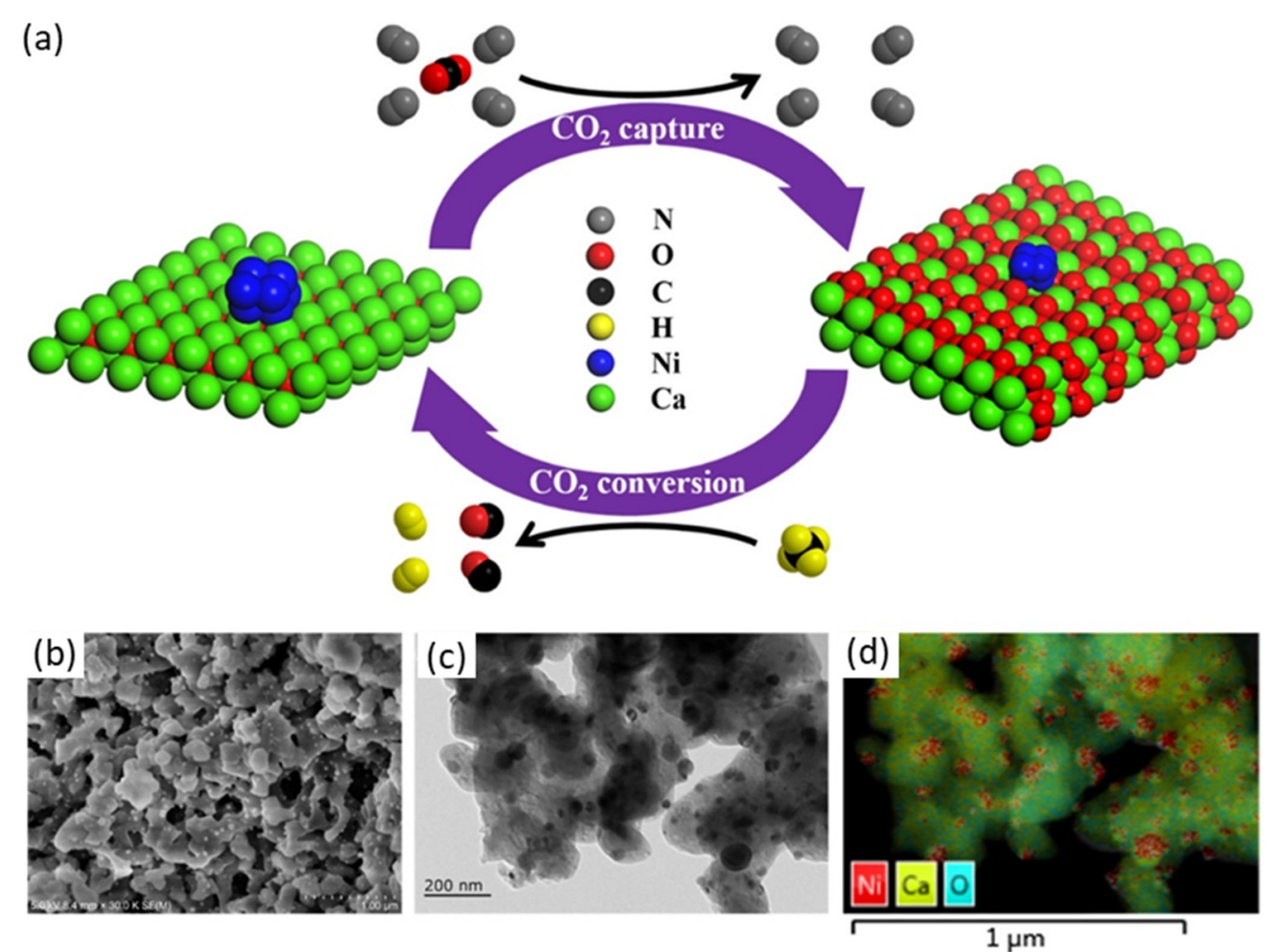

Figure 15. Illustration of the combined calcium looping and dry reforming process. (a) Process schematic, (b) particle shape and (c,d) structure and element map of the CaO-Ni multifunctional material (reduced $\mathrm{CaO} / \mathrm{Ni}$ ) [83].

Another example of functional chemical looping development is found in coupling $\mathrm{CO}_{2}$ sorption to oxygen storage reduction/oxidation, e.g., for energy storage [84-86]. The working principle of such combined chemical looping system can be described as 
"chemical charge" and "discharge" cycles (Figure 16). During reduction ("charge"), a feed of $\mathrm{CH}_{4}$ and $\mathrm{CO}_{2}$ is sent over a mechanical mixture of $\mathrm{Fe}_{3} \mathrm{O}_{4}$ and $\mathrm{CaO}$. Methane reduces $\mathrm{Fe}_{3} \mathrm{O}_{4}$ to metallic iron, while producing surface carbon as well as $\mathrm{CO}_{2}, \mathrm{H}_{2} \mathrm{O}$ and $\mathrm{H}_{2}$ (Equations (5) and (6)). The obtained $\mathrm{H}_{2}$ can be used for fuel cells. In parallel, $\mathrm{CaO}$ is carbonated to $\mathrm{CaCO}_{3}$ by interaction with $\mathrm{CO}_{2}$ (Equation (7)), typically at temperatures between 600 and $700{ }^{\circ} \mathrm{C}$ [87]:

$$
\begin{gathered}
\mathrm{CH}_{4}+\mathrm{Fe}_{3} \mathrm{O}_{4} \rightarrow 2 \mathrm{H}_{2} \mathrm{O}+\mathrm{CO}_{2}+3 \mathrm{Fe} \\
\mathrm{CH}_{4} \rightarrow \mathrm{C}+2 \mathrm{H}_{2} \\
\mathrm{CaO}+\mathrm{CO}_{2} \rightarrow \mathrm{CaCO}_{3}
\end{gathered}
$$

Depending on the need, the "charged" condition of the material can be preserved, or immediately put to use. For the latter case of "discharge", it is sufficient to increase the temperature of the sample by $50-150{ }^{\circ} \mathrm{C}$, which will trigger decomposition of $\mathrm{CaCO}_{3}$ back into $\mathrm{CaO}$ and $\mathrm{CO}_{2}$ (Equation (8)) [88]:

$$
\mathrm{CaCO}_{3} \rightarrow \mathrm{CaO}+\mathrm{CO}_{2}
$$

Simultaneously, the released $\mathrm{CO}_{2}$ will interact with metallic iron and with carbon deposited in the first step to produce $\mathrm{CO}$ :

$$
\begin{gathered}
4 \mathrm{CO}_{2}+3 \mathrm{Fe} \rightarrow \mathrm{Fe}_{3} \mathrm{O}_{4}+4 \mathrm{CO} \\
\mathrm{C}+\mathrm{CO}_{2} \rightarrow 2 \mathrm{CO}
\end{gathered}
$$

The $\mathrm{CO}$ that is generated can be used, e.g., in a solid oxide fuel cell (SOFC). Since $\mathrm{CO}$ intrinsically contains as much energy as hydrogen, it can indeed be oxidized electrochemically, $\mathrm{CO}+\mathrm{O}^{2-}=\mathrm{CO}_{2}+2 \mathrm{e}^{-}$, to produce electricity and $\mathrm{CO}_{2}$. The energetics of $\mathrm{CO}$ and $\mathrm{H}_{2}$ oxidation, calculated from thermochemical data at $1123 \mathrm{~K}$, yield similar values for the standard Gibbs free energy, i.e., $-185 \mathrm{~kJ} \mathrm{~mol}^{-1}$ for $\mathrm{CO}_{2}$ vs. $-186 \mathrm{~kJ} \mathrm{~mol}^{-1}$ for $\mathrm{H}_{2} \mathrm{O}$. Moreover, the CO oxidation reaction is slightly more exothermic than that of $\mathrm{H}_{2}$, i.e., $-282 \mathrm{~kJ} \mathrm{~mol}^{-1}$ for $\mathrm{CO}_{2}$ vs. $-249 \mathrm{~kJ} \mathrm{~mol}^{-1}$ for $\mathrm{H}_{2} \mathrm{O}$, underlining the $\mathrm{CO}$ potential for fuel cell use.

\section{Step I. Charge}

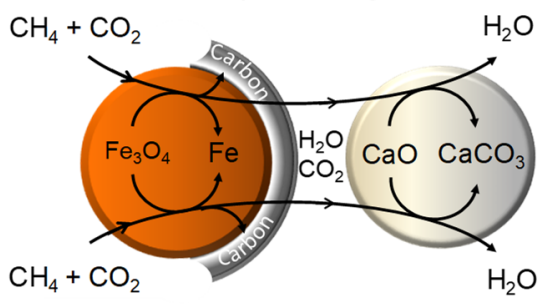

Step II. Discharge

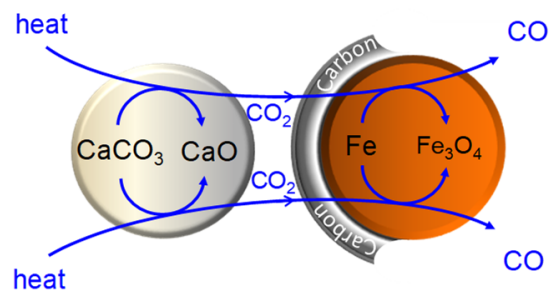

Figure 16. Illustration and working scheme of "combined chemical looping" for energy storage and conversion [84].

As exemplified before, adding a Ni catalyst can intensify the overall process. The mixture of $\mathrm{CH}_{4}$ and $\mathrm{CO}_{2}$ is converted to syngas over the catalyst by dry reforming. The 
latter will reduce iron oxide faster and deeper than the originally fed $\mathrm{CH}_{4}$. Figure $17 \mathrm{a}$ shows space-time yields of $\mathrm{CH}_{4}, \mathrm{CO}, \mathrm{CO}_{2}$ and $\mathrm{H}_{2}$ as a function of time-on-stream.
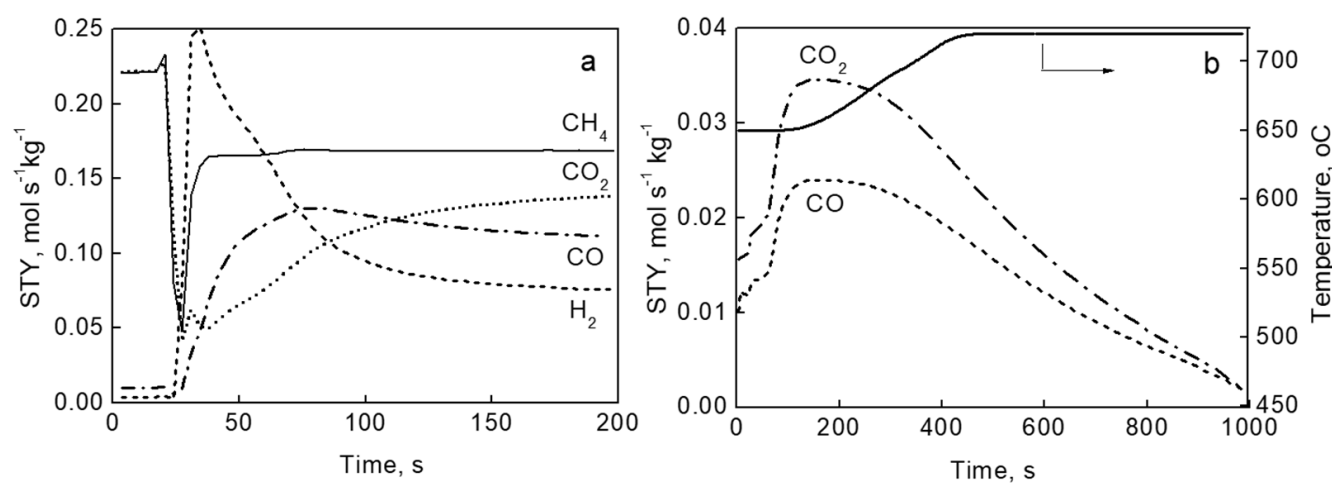

Figure 17. Space-time yield vs. time-on-stream for combined $\mathrm{CO}_{2}$ capture and $\mathrm{Fe}_{3} \mathrm{O}_{4}$ reduction over a $\mathrm{NiO} / \mathrm{Fe}_{2} \mathrm{O}_{3}-\mathrm{CeO}_{2}$ and $\mathrm{CaO}-\mathrm{Al}_{2} \mathrm{O}_{3}$ (1:5) mix. (a) $\mathrm{CaO}$ carbonation and $\mathrm{Fe}_{3} \mathrm{O}_{4}$ reduction with $\mathrm{CH}_{4}+\mathrm{CO}_{2}(1: 1)$ at $650^{\circ} \mathrm{C}$, and $(\mathbf{b}) \mathrm{CaCO}_{3}$ decarbonation and $\mathrm{CO}$ production by iron and carbon oxidation by $\mathrm{CO}_{2}$. Temperature rise from 650 to $720^{\circ} \mathrm{C}$ in He. Solid line: temperature profile [84].

Initially, $\mathrm{CO}_{2}$ decreases because it gets adsorbed by $\mathrm{CaO}$ and consumed in dry reforming. Once $\mathrm{CaO}$ is fully loaded with $\mathrm{CO}_{2}$, the $\mathrm{CO}_{2}$ space-time yield increases again to stabilize with the other products. Due to consumption of $\mathrm{CO}_{2}, \mathrm{CH}_{4}$ equally exhibits a minimum as it decomposes over $\mathrm{Ni}$, forming surface carbon and hydrogen. The space-time yield for $\mathrm{H}_{2}$ rises and goes through a maximum before levelling off. $\mathrm{Fe}_{3} \mathrm{O}_{4}$ gets reduced by both $\mathrm{CO}$ and $\mathrm{H}_{2}$. If needed, the process can be halted at this point to store the energy, delaying the "discharge" in time. For putting the stored energy to use, it suffices to purge the reactor with inert and raise the temperature slightly, from 650 to $720^{\circ} \mathrm{C}$. This will release the $\mathrm{CO}_{2}$ by $\mathrm{CaCO}_{3}$ decomposition and consecutively produce $\mathrm{CO}$ by $\mathrm{CO}_{2}$ oxidation of iron and carbon (Figure 17b).

This concept is widely flexible in both energy storage/release and fuel type. Dilute gas streams can be used for charging, an attractive factor for present-day applications. A further asset is that energy use or discharge and charge can easily be separated in time. Moreover, it can be merged with the newly developed solid oxide metal-air redox battery, based on oxide-ion chemistry. As such, combined chemical looping enables an emerging and promising energy storage technology, capable of harvesting renewable energy with high efficiency and of managing grid stability [89-91].

\section{Conclusions}

Chemical looping offers unseen opportunities for power plants and industrial applications with $\mathrm{CO}_{2}$ capture. It is a very promising technology with large potential, well beyond combustion, and it allows to intensify processes both in fuel and chemical production technology. The flexibility of the chemical looping platform stems from the separation of a single reaction into two sub-reactions, connected by a solid carrier material. The design of suitable carrier materials is therefore key to developing novel chemical looping processes. The latter should essentially focus on acquiring understanding on how structural and compositional architecture of both the metal component and the support structure impact on the performance of the chemical looping process. Guided by this insight, catalytic sites and carrier material can be tailored to strongly enhance the process, as shown here for $\mathrm{H}_{2}$ or $\mathrm{CO}$ production via methane reforming.

The principle of chemical looping is fundamentally applicable to any catalytic reaction, if suitable carriers are found that allow transport of the desired functional group. Moreover, it can be merged with existing catalytic processes for improved selectivity and stability. The inherent product separation can have a significant impact on a broad range of chemical processes, aiming for higher efficiency and 'greener' chemistry. We hope that this review 
can trigger both experimental investigation and scientific discussions that can lead to accelerated installation of chemical looping processes.

Author Contributions: Writing-review and editing, H.P.; writing-review and editing, V.V.G. All authors have read and agreed to the published version of the manuscript.

Funding: This research received no external funding.

Conflicts of Interest: The authors declare no conflict of interest.

\section{References}

1. Davis, S.J.; Lewis, N.S.; Shaner, M.; Aggarwal, S.; Arent, D.; Azevedo, I.L.; Benson, S.M.; Bradley, T.; Brouwer, J.; Chiang, Y.-M.; et al. Net-zero emissions energy systems. Science 2018, 360, eaas9793. [CrossRef] [PubMed]

2. Martens, J.A.; Bogaerts, A.; De Kimpe, N.; Jacobs, P.A.; Marin, G.B.; Rabaey, K.; Saeys, M.; Verhelst, S. The Chemical Route to a Carbon Dioxide Neutral World. ChemSusChem 2017, 10, 1039-1055. [CrossRef]

3. Wismann, S.T.; Engbæk, J.S.; Vendelbo, S.B.; Bendixen, F.B.; Eriksen, W.L.; Aasberg-Petersen, K.; Frandsen, C.; Chorkendorff, I.; Mortensen, P.M. Electrified methane reforming: A compact approach to greener industrial hydrogen production. Science 2019, 364, 756-759. [CrossRef]

4. Vooradi, R.; Bertran, M.-O.; Frauzem, R.; Anne, S.B.; Gani, R. Sustainable chemical processing and energy-carbon dioxide management: Review of challenges and opportunities. Chem. Eng. Res. Des. 2018, 131, 440-464. [CrossRef]

5. Takht Ravanchi, M.; Sahebdelfar, S. Catalytic conversions of $\mathrm{CO}_{2}$ to help mitigate climate change: Recent process develop-ments. Process. Saf. Environ. Prot. 2021, 145, 172-194. [CrossRef]

6. Flores-Granobles, M.; Saeys, M. Minimizing $\mathrm{CO}_{2}$ emissions with renewable energy: A comparative study of emerging technologies in the steel industry. Energy Environ. Sci. 2020, 13, 1923-1932. [CrossRef]

7. Abuelgasim, S.; Wang, W.; Abdalazeez, A. A brief review for chemical looping combustion as a promising $\mathrm{CO}_{2}$ capture technology: Fundamentals and progress. Sci. Total Environ. 2021, 764, 142892. [CrossRef]

8. Zhu, X.; Imtiaz, Q.; Donat, F.; Müller, C.R.; Li, F. Chemical looping beyond combustion-A perspective. Energy Environ. Sci. 2020, 13, 772-804. [CrossRef]

9. Di Giuliano, A.; Gallucci, K. Sorption enhanced steam methane reforming based on nickel and calcium looping: A review. Chem. Eng. Process. Process. Intensif. 2018, 130, 240-252. [CrossRef]

10. Kathe, M.; Empfield, A.; Sandvik, P.; Fryer, C.; Zhang, Y.; Blair, E.; Fan, L.-S. Utilization of $\mathrm{CO}_{2}$ as a partial substitute for methane feedstock in chemical looping methane-steam redox processes for syngas production. Energy Environ. Sci. 2017, 10, 1345-1349. [CrossRef]

11. Dang, C.; Li, Y.; Yusuf, S.M.; Cao, Y.; Wang, H.; Yu, H.; Peng, F.; Li, F. Calcium cobaltate: A phase-change catalyst for stable hydrogen production from bio-glycerol. Energy Environ. Sci. 2018, 11, 660-668. [CrossRef]

12. Zhao, X.; Zhou, H.; Sikarwar, V.S.; Zhao, M.; Park, A.-H.A.; Fennell, P.S.; Shen, L.; Fan, L.-S. Biomass-based chemical looping technologies: The good, the bad and the future. Energy Environ. Sci. 2017, 10, 1885-1910. [CrossRef]

13. Zeng, L.; Cheng, Z.; Fan, J.A.; Fan, L.-S.; Gong, J. Metal oxide redox chemistry for chemical looping processes. Nat. Rev. Chem. 2018, 2, 349-364. [CrossRef]

14. Li, D.; Xu, R.; Li, X.; Li, Z.; Zhu, X.; Li, K. Chemical Looping Conversion of Gaseous and Liquid Fuels for Chemical Production: A Review. Energy Fuels 2020, 34, 5381-5413. [CrossRef]

15. Adanez, J.; Abad, A.; Garcia-Labiano, F.; Gayan, P.; De Diego, L.F. Progress in Chemical-Looping Combustion and Reforming technologies. Prog. Energy Combust. Sci. 2012, 38, 215-282. [CrossRef]

16. Fan, L.-S.; Zeng, L.; Luo, S. Chemical-looping technology platform. AIChE J. 2014, 61, 2-22. [CrossRef]

17. Yan, X.; Li, Y.; Ma, X.; Zhao, J.; Wang, Z. Performance of $\mathrm{Li}_{4} \mathrm{SiO}_{4}$ material for $\mathrm{CO}_{2}$ capture: A review. Int. J. Mol. Sci. 2019, 20, 928. [CrossRef]

18. Kim, S.M.; Abdala, P.M.; Broda, M.; Hosseini, D.; Copéret, C.; Müller, C. Integrated $\mathrm{CO}_{2}$ Capture and Conversion as an Efficient Process for Fuels from Greenhouse Gases. ACS Catal. 2018, 8, 2815-2823. [CrossRef]

19. Fan, L.-S. Chemical Looping Systems for Fossil Energy Conversions; John Wiley and Sons Inc.: Hoboken, NJ, USA, 2010.

20. Criado, Y.A.; Arias, B.; Abanades, J.C. Calcium looping $\mathrm{CO}_{2}$ capture system for back-up power plants. Energy Environ. Sci. 2017, 10, 1994-2004. [CrossRef]

21. Blamey, J.; Anthony, E.J.; Wang, J.; Fennell, P.S. The calcium looping cycle for large-scale $\mathrm{CO}_{2}$ capture. Prog. Energy Combust. Sci. 2010, 36, 260-279. [CrossRef]

22. Tian, H.; Simonyi, T.; Poston, J.; Siriwardane, R. Effect of Hydrogen Sulfide on Chemical Looping Combustion of Coal-Derived Synthesis Gas over Bentonite-Supported Metal-Oxide Oxygen Carriers. Ind. Eng. Chem. Res. 2009, 48, 8418-8430. [CrossRef]

23. Kane, T.; Guerrero Caballero, J.; Löfberg, A. Chemical looping selective oxidation of $\mathrm{H}_{2} \mathrm{~S}$ using $\mathrm{V}_{2} \mathrm{O}_{5}$ impregnated over different supports as oxygen carriers. Chem CatChem 2020, 12, 2569-2579. [CrossRef]

24. Zhu, J.; Sushkevich, V.L.; Knorpp, A.J.; Newton, M.A.; Mizuno, S.C.M.; Wakihara, T.; Okubo, T.; Liu, Z.; Van Bokhoven, J.A. $\mathrm{Cu}$-Erionite Zeolite Achieves High Yield in Direct Oxidation of Methane to Methanol by Isothermal Chemical Looping. Chem. Mater. 2020, 32, 1448-1453. [CrossRef] 
25. Ishida, M.; Zheng, D.; Akehata, T. Evaluation of a chemical-looping-combustion power-generation system by graphic exergy analysis. Energy 1987, 12, 147-154. [CrossRef]

26. Richter, H.J.; Knoche, K.F. Reversibility of Combustion Processes. ACS Symp. Ser. 1983, 235, 71-85. [CrossRef]

27. Mattisson, T.; Keller, M.; Linderholm, C.; Moldenhauer, P.; Rydén, M.; Leion, H.; Lyngfelt, A. Chemical-looping technologies using circulating fluidized bed systems: Status of development. Fuel Process. Technol. 2018, 172, 1-12. [CrossRef]

28. Huang, J.; Liu, W.; Yang, Y.; Liu, B. High-Performance Ni-Fe Redox Catalysts for Selective CH4 to Syngas Conversion via Chemical Looping. ACS Catal. 2018, 8, 1748-1756. [CrossRef]

29. Mihai, O.; Chen, D.; Holmén, A. Catalytic Consequence of Oxygen of Lanthanum Ferrite Perovskite in Chemical Looping Reforming of Methane. Ind. Eng. Chem. Res. 2011, 50, 2613-2621. [CrossRef]

30. Lyngfelt, A. Oxygen Carriers for Chemical-Looping Combustion. In Calcium and Chemical Looping Technology for Power Generation and Carbon Dioxide $\left(\mathrm{CO}_{2}\right)$ Capture; Fennell, P., Anthony, B., Eds.; Woodhead Publishing: Cambridge, UK, 2015; Chapter 11; pp. 221-254.

31. Solunke, R.D.; Veser, G. Integrating desulfurization with $\mathrm{CO}_{2}$-capture in chemical-looping combustion. Fuel 2011, 90, 608-617. [CrossRef]

32. Dou, Y.; Sun, L.; Ren, J.; Dong, L. Opportunities and future challenges in hydrogen economy for sustainable development. In Hydrogen Economy; Scipioni, A., Manzardo, A., Ren, J., Eds.; Academic Press: Cambridge, MA, USA, 2017; Chapter 10; pp. 277-305.

33. Nehrir, M.H.; Wang, C. Fuel cells. In Electric Renewable Energy Systems; Rashid, M.H., Ed.; Academic Press: Boston, MA, USA, 2016; Chapter 6; pp. 92-113.

34. Song, C. Fuel processing for low-temperature and high-temperature fuel cells Challenges, and opportunities for sustainable development in the 21st century. Catal. Today 2002, 77, 17-49. [CrossRef]

35. Choudhary, T.V.; Goodman, D.W. Co-free fuel processing for fuel cell applications. Catal. Today 2002, 77, 65-78. [CrossRef]

36. Liu, W.; Lim, J.Y.; Saucedo, M.A.; Hayhurst, A.N.; Scott, S.A.; Dennis, J. Kinetics of the reduction of wüstite by hydrogen and carbon monoxide for the chemical looping production of hydrogen. Chem. Eng. Sci. 2014, 120, 149-166. [CrossRef]

37. Galvita, V.; Sundmacher, K. Cyclic water gas shift reactor (CWGS) for carbon monoxide removal from hydrogen feed gas for PEM fuel cells. Chem. Eng. J. 2007, 134, 168-174. [CrossRef]

38. Buelens, L.C.; Galvita, V.V.; Poelman, H.; Detavernier, C.; Marin, G.B. Super-dry reforming of methane intensifies $\mathrm{CO}_{2}$ utili-zation via le chatelier's principle. Science 2016, 354, 449-452. [CrossRef]

39. Galvita, V.V.; Poelman, H.; Marin, G.B. Hydrogen Production from Methane and Carbon Dioxide by Catalyst-Assisted Chemical Looping. Top. Catal. 2011, 54, 907-913. [CrossRef]

40. Najera, M.; Solunke, R.; Gardner, T.; Veser, G. Carbon capture and utilization via chemical looping dry reforming. Chem. Eng. Res. Des. 2011, 89, 1533-1543. [CrossRef]

41. Bhavsar, S.; Nájera, M.; Veser, G. Chemical Looping Dry Reforming as Novel, Intensified Process for $\mathrm{CO}_{2}$ Activation. Chem. Eng. Technol. 2012, 35, 1281-1290. [CrossRef]

42. Hu, J.; Galvita, V.V.; Poelman, H.; Marin, G.B. Advanced Chemical Looping Materials for $\mathrm{CO}_{2}$ Utilization: A Review. Materials 2018, 11, 1187. [CrossRef]

43. Loutzenhiser, P.G.; Gálvez, M.E.; Hischier, I.; Stamatiou, A.; Frei, A.; Steinfeld, A. $\mathrm{CO}_{2}$ splitting via two-step solar thermo-chemical cycles with zn/zno and $\mathrm{FeO} / \mathrm{Fe}_{3} \mathrm{O}_{4}$ redox reactions ii: Kinetic analysis. Energy Fuels 2009, 23, 2832-2839. [CrossRef]

44. Galvita, V.; Hempel, T.; Lorenz, H.; Rihko-Struckmann, L.K.; Sundmacher, K. Deactivation of Modified Iron Oxide Materials in the Cyclic Water Gas Shift Process for CO-Free Hydrogen Production. Ind. Eng. Chem. Res. 2008, 47, 303-310. [CrossRef]

45. Theofanidis, S.A.; Galvita, V.V.; Poelman, H.; Marin, G.B. Enhanced Carbon-Resistant Dry Reforming Fe-Ni Catalyst: Role of Fe. ACS Catal. 2015, 5, 3028-3039. [CrossRef]

46. Daza, C.E.; Kiennemann, A.; Moreno, S.; Molina, R. Dry reforming of methane using Ni-Ce catalysts supported on a modified mineral clay. Appl. Catal. A Gen. 2009, 364, 65-74. [CrossRef]

47. Potdar, H.S.; Roh, H.-S.; Jun, K.-W.; Ji, M.; Liu, Z.-W. Carbon dioxide reforming of methane over co-precipitated Ni-Ce-ZrO 2 catalysts. Catal. Lett. 2002, 84, 95-100.

48. Galvita, V.V.; Poelman, H.; Detavernier, C.; Marin, G.B. Catalyst-assisted chemical looping for $\mathrm{CO}_{2}$ conversion to CO. Appl. Catal. B Environ. 2015, 164, 184-191. [CrossRef]

49. Yin, X.; Wang, S.; Sun, R.; Jiang, S.; Shen, L.-H. A Ce-Fe Oxygen Carrier with a Core-Shell Structure for Chemical Looping Steam Methane Reforming. Ind. Eng. Chem. Res. 2020, 59, 9775-9786. [CrossRef]

50. Galinsky, N.L.; Shafiefarhood, A.; Chen, Y.; Neal, L.; Li, F. Effect of support on redox stability of iron oxide for chemical looping conversion of methane. Appl. Catal. B Environ. 2015, 164, 371-379. [CrossRef]

51. Tang, M.; Xu, L.; Fan, M. Progress in oxygen carrier development of methane-based chemical-looping reforming: A review. Appl. Energy 2015, 151, 143-156. [CrossRef]

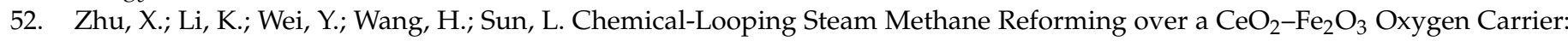
Evolution of Its Structure and Reducibility. Energy Fuels 2014, 28, 754-760. [CrossRef]

53. Galvita, V.V.; Poelman, H.; Bliznuk, V.; Detavernier, C.; Marin, G.B. $\mathrm{CeO}_{2}$-modified $\mathrm{Fe}_{2} \mathrm{O}_{3}$ for $\mathrm{CO}_{2}$ utilization via chemical looping. Ind. Eng. Chem. Res. 2013, 52, 8416-8426. [CrossRef] 
54. Dharanipragada, N.V.R.A.; Meledina, M.; Galvita, V.V.; Poelman, H.; Turner, S.; Van Tendeloo, G.; Detavernier, C.; Marin, G.B. Deactivation Study of $\mathrm{Fe}_{2} \mathrm{O}_{3}-\mathrm{CeO}_{2}$ during Redox Cycles for $\mathrm{CO}$ Production from $\mathrm{CO}_{2}$. Ind. Eng. Chem. Res. 2016, 55, 5911-5922. [CrossRef]

55. Dharanipragada, N.A.; Galvita, V.V.; Poelman, H.; Buelens, L.C.; Detavernier, C.; Marin, G.B. Bifunctional Co- and Ni-ferrites for catalyst-assisted chemical looping with alcohols. Appl. Catal. B Environ. 2018, 222, 59-72. [CrossRef]

56. $\mathrm{Hu}$, J.; Buelens, L.; Theofanidis, S.-A.; Galvita, V.V.; Poelman, H.; Marin, G.B. $\mathrm{CO}_{2}$ conversion to CO by autothermal cata-lystassisted chemical looping. J. CO2 Util. 2016, 16, 8-16. [CrossRef]

57. Sun, Z.; Chen, S.; Hu, J.; Chen, A.; Rony, A.H.; Russell, C.K.; Xiang, W.; Fan, M.; Dyar, M.D.; Dklute, E.C. Ca $2 \mathrm{Fe}_{2} \mathrm{O}_{5}$ : A promising oxygen carrier for $\mathrm{CO} / \mathrm{CH}_{4}$ conversion and almost-pure $\mathrm{H}_{2}$ production with inherent $\mathrm{CO}_{2}$ capture over a two-step chemical looping hydrogen generation process. Appl. Energy 2018, 211, 431-442. [CrossRef]

58. Liu, S.; Xiang, D.; Xu, Y.; Sun, Z.; Cao, Y. Relationship between electronic properties of $\mathrm{Fe}_{3} \mathrm{O}_{4}$ substituted by Ca and Ba and their reactivity in chemical looping process: A first-principles study. Appl. Energy 2017, 202, 550-557. [CrossRef]

59. Chan, M.S.; Liu, W.; Ismail, M.; Yang, Y.; Scott, S.A.; Dennis, J.S. Improving hydrogen yields, and hydrogen:steam ratio in the chemical looping production of hydrogen using $\mathrm{Ca}_{2} \mathrm{Fe}_{2} \mathrm{O}_{5}$. Chem. Eng. J. 2016, 296, 406-411. [CrossRef]

60. Sun, Z.; Chen, S.; Russell, C.K.; Hu, J.; Rony, A.H.; Tan, G.; Chen, A.; Duan, L.; Boman, J.; Tang, J.; et al. Improvement of $\mathrm{H}_{2}$-rich gas production with tar abatement from pine wood conversion over bi-functional $\mathrm{Ca}_{2} \mathrm{Fe}_{2} \mathrm{O}_{5}$ catalyst: Investigation of inner-looping redox reaction and promoting mechanisms. Appl. Energy 2018, 212, 931-943. [CrossRef]

61. Hosseini, D.; Donat, F.; Abdala, P.M.; Kim, S.M.; Kierzkowska, A.M.; Müller, C.R. Reversible Exsolution of Dopant Improves the Performance of $\mathrm{Ca}_{2} \mathrm{Fe}_{2} \mathrm{O}_{5}$ for Chemical Looping Hydrogen Production. ACS Appl. Mater. Interfaces 2019, 11, 18276-18284. [CrossRef]

62. Carrillo, A.J.; Kim, K.J.; Hood, Z.D.; Bork, A.H.; Rupp, J.L.M. La0.6Sr0.4Cr0.8Co0.2O3 Perovskite Decorated with Exsolved Co Nanoparticles for Stable $\mathrm{CO}_{2}$ Splitting and Syngas Production. ACS Appl. Energy Mater. 2020, 3, 4569-4579. [CrossRef]

63. Kousi, K.; Neagu, D.; Bekris, L.; Papaioannou, E.I.; Metcalfe, I.S. Endogenous Nanoparticles Strain Perovskite Host Lattice Providing Oxygen Capacity and Driving Oxygen Exchange and $\mathrm{CH}_{4}$ Conversion to Syngas. Angew. Chem. Int. Ed. 2019, 59, 2510-2519. [CrossRef]

64. Otto, S.-K.; Kousi, K.; Neagu, D.; Bekris, L.; Janek, J.; Metcalfe, I.S. Exsolved Nickel Nanoparticles Acting as Oxygen Storage Reservoirs and Active Sites for Redox CH4 Conversion. ACS Appl. Energy Mater. 2019, 2, 7288-7298. [CrossRef]

65. Gärtner, C.A.; van Veen, A.C.; Lercher, J.A. Oxidative dehydrogenation of ethane: Common principles and mechanistic as-pects. ChemCatChem 2013, 5, 3196-3217. [CrossRef]

66. Bañares, M.A. Supported metal oxide and other catalysts for ethane conversion: A review. Catal. Today 1999, 51, 319-348. [CrossRef]

67. Nowicka, E.; Reece, C.; Althahban, S.M.; Mohammed, K.M.H.; Kondrat, S.A.; Morgan, D.J.; He, Q.; Willock, D.J.; Golunski, S.; Kiely, C.J.; et al. Elucidating the Role of $\mathrm{CO}_{2}$ in the Soft Oxidative Dehydrogenation of Propane over Ceria-Based Catalysts. ACS Catal. 2018, 8, 3454-3468. [CrossRef]

68. Gao, Y.; Haeri, F.; He, F.; Li, F. Alkali metal-promoted $\mathrm{LaxSr}_{2}-\mathrm{xFeO}_{4}-\delta$ redox catalysts for chemical looping oxidative dehydrogenation of ethane. ACS Catal. 2018, 8, 1757-1766. [CrossRef]

69. Yusuf, S.; Neal, L.; Bao, Z.; Wu, Z.; Li, F. Effects of sodium and tungsten promoters on mg6mno8-based core-shell redox cat-alysts for chemical looping-oxidative dehydrogenation of ethane. ACS Catal. 2019, 9, 3174-3186. [CrossRef]

70. Galinsky, N.; Sendi, M.; Bowers, L.; Li, F. CaMn1-xBxO $3-\delta(b=A l, V, F e, C o$ and Ni) perovskite based oxygen carriers for chemical looping with oxygen uncoupling (clou). Appl. Energy 2016, 174, 80-87. [CrossRef]

71. Kang, D.; Lim, H.S.; Lee, M.; Lee, J.W. Syngas production on a Ni-enhanced $\mathrm{Fe}_{2} \mathrm{O}_{3} / \mathrm{Al}_{2} \mathrm{O}_{3}$ oxygen carrier via chemical looping partial oxidation with dry reforming of methane. Appl. Energy 2018, 211, 174-186. [CrossRef]

72. Brady, C.; Murphy, B.; Xu, B. Enhanced methane dehydroaromatization via coupling with chemical looping. ACS Catal. 2017, 7, 3924-3928. [CrossRef]

73. Zhang, X.; Pei, C.; Chang, X.; Chen, S.; Liu, R.; Zhao, Z.-J.; Mu, R.; Gong, J. FeO 6 Octahedral Distortion Activates Lattice Oxygen in Perovskite Ferrite for Methane Partial Oxidation Coupled with $\mathrm{CO}_{2}$ Splitting. J. Am. Chem. Soc. 2020, 142, 11540-11549. [CrossRef] [PubMed]

74. Gao, W.; Guo, J.; Wang, P.; Wang, Q.; Chang, F.; Pei, Q.; Zhang, W.; Liu, L.; Chen, P. Production of ammonia via a chemical looping process based on metal imides as nitrogen carriers. Nat. Energy 2018, 3, 1067-1075. [CrossRef]

75. Lyon, R.K.; Cole, J.A. Unmixed combustion: An alternative to fire. Combust. Flame 2000, 121, 249-261. [CrossRef]

76. Martavaltzi, C.S.; Lemonidou, A.A. Development of new $\mathrm{CaO}$ based sorbent materials for $\mathrm{CO}_{2}$ removal at high temperature. Microporous Mesoporous Mater. 2008, 110, 119-127. [CrossRef]

77. Fernández, J.; Abanades, J. Optimized design and operation strategy of a CaCu chemical looping process for hydrogen production. Chem. Eng. Sci. 2017, 166, 144-160. [CrossRef]

78. Antzara, A.; Heracleous, E.; Bukur, D.B.; Lemonidou, A. Thermodynamic analysis of hydrogen production via chemical looping steam methane reforming coupled with in situ $\mathrm{CO}_{2}$ capture. Int. J. Greenh. Gas Control. 2015, 32, 115-128. [CrossRef]

79. Martavaltzi, C.S.; Pampaka, E.P.; Korkakaki, E.S.; Lemonidou, A.A. Hydrogen Production via Steam Reforming of Methane with Simultaneous $\mathrm{CO}_{2}$ Capture over $\mathrm{CaO}-\mathrm{Ca}_{12} \mathrm{Al}_{14} \mathrm{O}_{33}$. Energy Fuels 2010, 24, 2589-2595. [CrossRef] 
80. Antzara, A.; Heracleous, E.; Lemonidou, A.A. Energy efficient sorption enhanced-chemical looping methane reforming process for high-purity $\mathrm{H}_{2}$ production: Experimental proof-of-concept. Appl. Energy 2016, 180, 457-471. [CrossRef]

81. Li, H.; Dang, C.; Yang, G.; Cao, Y.; Wang, H.; Peng, F.; Yu, H. Bi-functional particles for integrated thermo-chemical processes: Catalysis and beyond. Particuology 2021. [CrossRef]

82. Verbeeck, K.; Buelens, L.C.; Galvita, V.V.; Marin, G.B.; Van Geem, K.M.; Rabaey, K. Upgrading the value of anaerobic digestion via chemical production from grid injected biomethane. Energy Environ. Sci. 2018, 11, 1788-1802.

83. Tian, S.; Yan, F.; Zhang, Z.; Jiang, J. Calcium-looping reforming of methane realizes in situ $\mathrm{CO}_{2}$ utilization with improved energy efficiency. Sci. Adv. 2019, 5, eaav5077. [CrossRef] [PubMed]

84. Galvita, V.V.; Poelman, H.; Marin, G.B. Combined chemical looping for energy storage and conversion. J. Power Sources 2015, 286, 362-370. [CrossRef]

85. Galvita, V.V.; Poelman, H.; Marin, G.B. Combined Chemical Looping: New Possibilities for Energy Storage and Conversion. Energy Fuels 2017, 31, 11509-11514. [CrossRef]

86. Saghafifar, M.; Schnellmann, M.A.; Scott, S.A. Chemical looping electricity storage. Appl. Energy 2020, 279, 115553. [CrossRef]

87. Abanades, J.C.; Alvarez, D. Conversion limits in the reaction of $\mathrm{CO}_{2}$ with lime. Energy Fuels 2003, 17, 308-315. [CrossRef]

88. Vorrias, I.; Atsonios, K.; Nikolopoulos, A.; Nikolopoulos, N.; Grammelis, P.; Kakaras, E. Calcium looping for $\mathrm{CO}_{2}$ capture from a lignite fired power plant. Fuel 2013, 113, 826-836. [CrossRef]

89. Zhang, C.; Huang, K. A comprehensive review on the development of solid-state metal-air batteries operated on oxide-ion chemistry. Adv. Energy Mater. 2021, 11, 2000630. [CrossRef]

90. Xu, N.; Li, X.; Zhao, X.; Goodenough, J.B.; Huang, K. A novel solid oxide redox flow battery for grid energy storage. Energy Environ. Sci. 2011, 4, 4942-4946. [CrossRef]

91. Menzler, N.H.; Hospach, A.; Niewolak, L.; Bram, M.; Tokariev, O.; Berger, C.M.; Orzessek, P.; Quadakkers, W.J.; Fang, Q.; Buchkremer, H.P. Power-To-Storage-The Use of an Anode-Supported Solid Oxide Fuel Cell as a High-Temperature Battery. ECS Trans. 2013, 57, 255-267. [CrossRef] 